\title{
Tuning Inner-Sphere Electron Transfer in a Series of Copper-Nitrosoarene Adducts
}

Mohammad S. Askari, ${ }^{a}$ Farshid Effaty, ${ }^{a}$ Federica Gennarini, ${ }^{a, b}$ Maylis Orio, ${ }^{c}$ Nicolas Le Poul, ${ }^{*, b} \mathrm{X}$. Ottenwaelder*,a

${ }^{a}$ Department of Chemistry and Biochemistry, Concordia University, Montreal, Canada

${ }^{b}$ Laboratoire de Chimie, Électrochimie Moléculaires et Chimie Analytique (UMR 6521), Université de Bretagne Occidentale, Brest, France

${ }^{c}$ Aix Marseille Université, CNRS, Centrale Marseille, iSm2, Marseille, France

\section{Table of Contents}

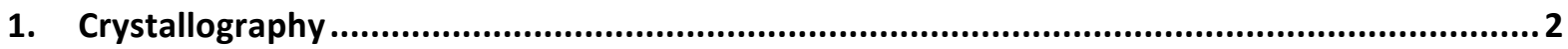

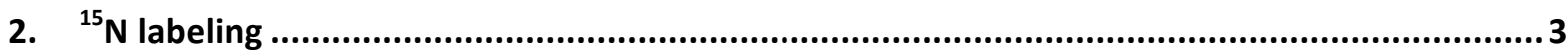

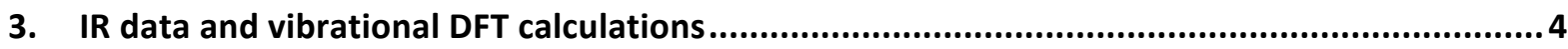

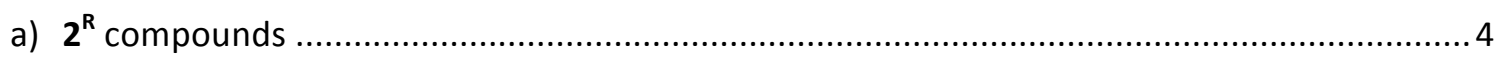

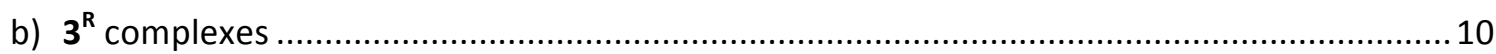

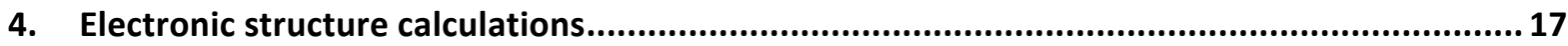

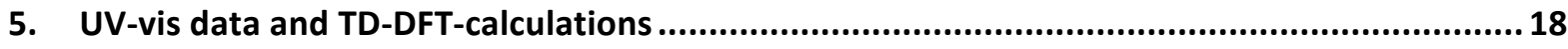

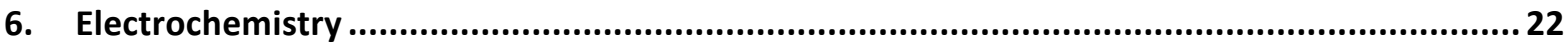

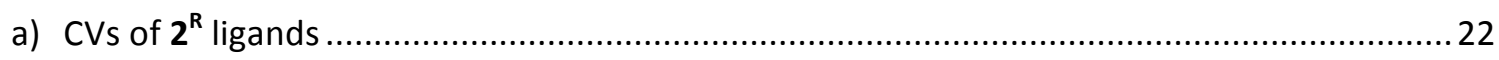

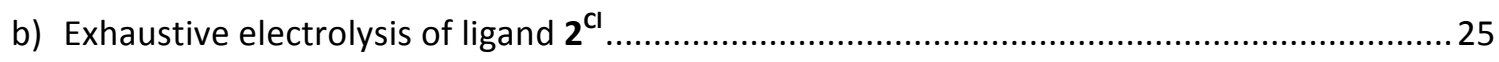

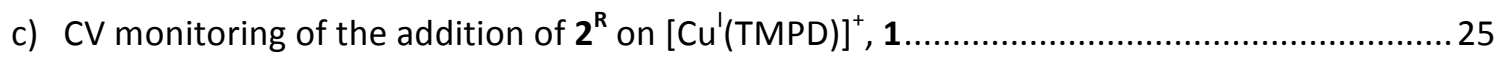

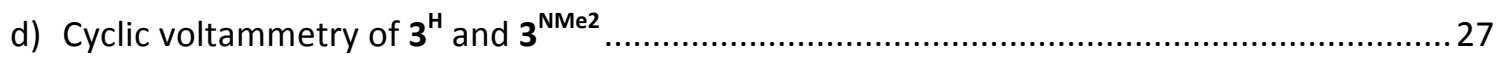

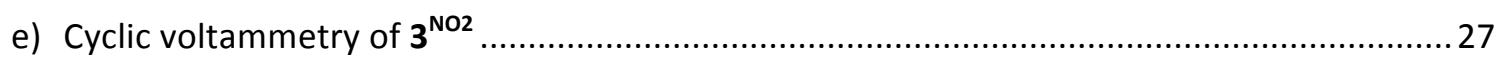

f) Comparative voltammetric studies of ligands and complexes ............................................2 28

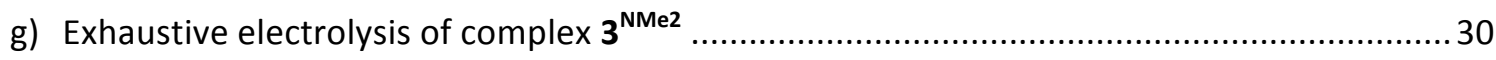

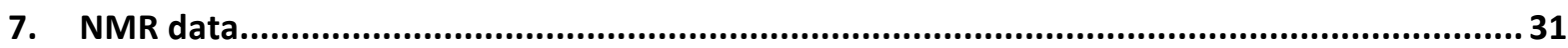

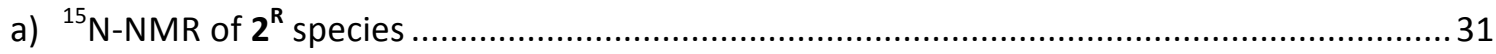

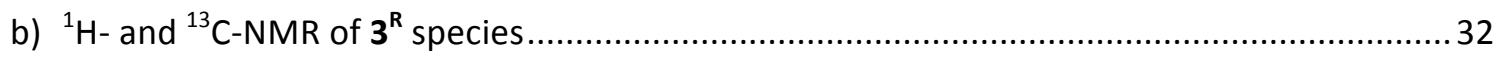

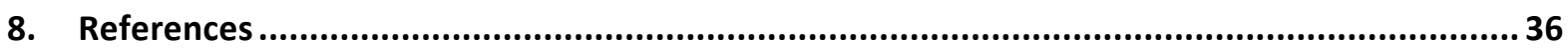




\section{Crystallography}

Note: the crystallographic data for $\mathbf{2}^{\mathrm{NO2}}$ is given in reference $\$^{1}$ (CCDC number 1029423).

Table S1. Crystallographic data for $\mathbf{3}^{\mathrm{R}}$ complexes $\left(\mathrm{R}=\mathrm{NMe}_{2}, \mathrm{H}\right.$ (two types of crystals) and $\mathrm{Cl}$ ).

\begin{tabular}{|c|c|c|c|c|}
\hline & $3^{\mathrm{NM} 2}$ & $3^{\mathrm{H}}$ & $3^{\mathrm{H}_{1}}$ & $3^{\mathrm{Cl}}$ \\
\hline CCDC number & 1959040 & 1959041 & 1959042 & 1959043 \\
\hline Empirical formula & $\mathrm{C}_{16} \mathrm{H}_{28} \mathrm{CuF}_{3} \mathrm{~N}_{4} \mathrm{O}_{4} \mathrm{~S}$ & $\mathrm{C}_{14} \mathrm{H}_{23} \mathrm{CuF}_{3} \mathrm{~N}_{3} \mathrm{O}_{4} \mathrm{~S}$ & $\mathrm{C}_{22} \mathrm{H}_{41} \mathrm{Cu}_{2} \mathrm{~F}_{6} \mathrm{~N}_{5} \mathrm{O}_{7} \mathrm{~S}_{2}$ & $\mathrm{C}_{14} \mathrm{H}_{22} \mathrm{ClCuF}_{3} \mathrm{~N}_{3} \mathrm{O}_{4} \mathrm{~S}$ \\
\hline Formula weight & 493.02 & 449.95 & 792.80 & 484.39 \\
\hline Temperature & $110(2) \mathrm{K}$ & $110(2) \mathrm{K}$ & $110(2) \mathrm{K}$ & 110(2) K \\
\hline Wavelength & $0.71073 \AA$ & $1.54178 \AA$ & $0.71073 \AA$ & $1.54178 \AA$ \\
\hline Crystal system & Monoclinic & Orthorhombic & Monoclinic & Monoclinic \\
\hline Space group & $\mathrm{P} 22_{1} / \mathrm{c}$ & $\mathrm{P}_{\mathrm{bca}}$ & $\mathrm{P} 2_{1} / \mathrm{n}$ & $\mathrm{P} 2_{1} / \mathrm{n}$ \\
\hline$a$ & $13.145(3) \AA$ & $7.80620(10) \AA$ & $8.0767(15) \AA ̊$ & $8.30960(10) \AA$ \\
\hline$b$ & $22.889(5) \AA$ & $15.1925(2) \AA$ & $14.497(3) \AA$ & $9.01090(10) \AA$ \\
\hline$c$ & $13.812(3) \AA$ & $31.5621(3) \AA$ & $27.890(5) \AA$ & $26.0825(3) \AA$ \\
\hline$\alpha$ & $90^{\circ}$ & $90^{\circ}$ & $90^{\circ}$ & $90^{\circ}$ \\
\hline B & $90.525(3)^{\circ}$ & $90^{\circ}$ & $91.131(2)^{\circ}$ & $91.47^{\circ}$ \\
\hline$\gamma$ & $90^{\circ}$ & $90^{\circ}$ & $90^{\circ}$ & $90^{\circ}$ \\
\hline Volume & $4155.6(14) \AA^{3}$ & $3743.13(8) \AA^{3}$ & $3265.0(10) \AA^{3}$ & $1952.34(4) \AA^{3}$ \\
\hline$z$ & 8 & 8 & 4 & 4 \\
\hline Density (calculated) & $1.576 \mathrm{~g} \mathrm{~cm}^{-3}$ & $1.597 \mathrm{~g} \mathrm{~cm}^{-3}$ & $1.613 \mathrm{~g} \mathrm{~cm}^{-3}$ & $1.648 \mathrm{~g} \mathrm{~cm}^{-3}$ \\
\hline Absorption coefficient & 1.208 & 3.194 & 1.511 & 4.340 \\
\hline$F(000)$ & 2048 & 1856 & 1632 & 992 \\
\hline Crystal size & $\begin{array}{l}0.392 \times 0.303 \times \\
0.080 \mathrm{~mm}\end{array}$ & $\begin{array}{l}0.268 \times 0.143 \times \\
0.118 \mathrm{~mm}\end{array}$ & $\begin{array}{l}0.502 \times 0.322 \times \\
0.120 \mathrm{~mm}\end{array}$ & $\begin{array}{l}0.328 \times 0.171 \times \\
0.144 \mathrm{~mm}\end{array}$ \\
\hline Index ranges & $h=-18 \rightarrow 18$ & $h=-9 \rightarrow 9$ & $h=-10 \rightarrow 10$ & $h=-9 \rightarrow 9$ \\
\hline & $k=-30 \rightarrow 29$ & $k=-17 \rightarrow 17$ & $k=-18 \rightarrow 18$ & $k=-10 \rightarrow 10$ \\
\hline & $I=-17 \rightarrow 17$ & $I=-37 \rightarrow 38$ & $I=-36 \rightarrow 36$ & $I=-31 \rightarrow 31$ \\
\hline Reflections collected & 50276 & 33717 & 37194 & 27371 \\
\hline Independent reflections & 9874 & 3491 & 7590 & 3550 \\
\hline Parameters & 535 & 239 & 402 & 248 \\
\hline Goodness of fit & 1.004 & 1.033 & 1.036 & 1.039 \\
\hline Final $R$ indices $[I>2 \sigma(I)]$ & $\begin{array}{l}R_{1}=6.53 \%, w R_{2}= \\
12.44 \%\end{array}$ & $\begin{array}{l}R_{1}=3.35 \%, w R_{2}= \\
8.31 \%\end{array}$ & $\begin{array}{l}R_{1}=4.80 \%, w R_{2}= \\
11.47 \%\end{array}$ & $\begin{array}{l}R_{1}=2.21 \%, w R_{2}= \\
5.87 \%\end{array}$ \\
\hline$R$ indices (all data) & $\begin{array}{l}R_{1}=16.93 \%, w R_{2}= \\
16.09 \%\end{array}$ & $\begin{array}{l}R_{1}=4.37 \%, w R_{2}= \\
8.82 \%\end{array}$ & $\begin{array}{l}R_{1}=6.66 \%, w R_{2}= \\
12.47 \%\end{array}$ & $\begin{array}{l}R_{1}=2.31 \%, w R_{2}= \\
5.93 \%\end{array}$ \\
\hline Largest diff. peak and hole & $\begin{array}{l}0.627 \text { and }-0.542 \\
\text { e } \AA^{-3}\end{array}$ & $\begin{array}{l}0.314 \text { and }-0.383 \\
\mathrm{e} \AA^{-3}\end{array}$ & $\begin{array}{l}2.806^{*} \text { and }-0.834 \\
\mathrm{e} \AA^{-3}\end{array}$ & $\begin{array}{l}0.297 \text { and }-0.393 \\
\mathrm{e} \AA^{-3}\end{array}$ \\
\hline
\end{tabular}

* This large residual peak, the only one so intense, is close to the $\mathrm{Cu}$ atom, has not chemical sense and is likely an artefact of the sample having a very small twin/crack. Duplicated and non-separable peaks on some frames were integrated together, leading to some discrepancies in intensity measurements. 


\section{2. $\quad{ }^{15} \mathrm{~N}$ labeling}

The $\mathbf{2}^{\mathrm{R}}$ compounds with ${ }^{15} \mathrm{~N}$-labeled nitroso function were prepared by the following procedures, from or inspired from the literature.

4-dimethylamino- ${ }^{15} \mathrm{~N}$-nitrosobenzene $\left({ }^{15 \mathrm{~N}} 2^{\mathrm{NMe2}}\right)$. This compound was prepared following a literature procedure, ${ }^{2}$ using regular water, commercial sodium nitrite- ${ }^{15} \mathrm{~N}$ and skipping the step of ${ }^{17} \mathrm{O}$-water evaporation.

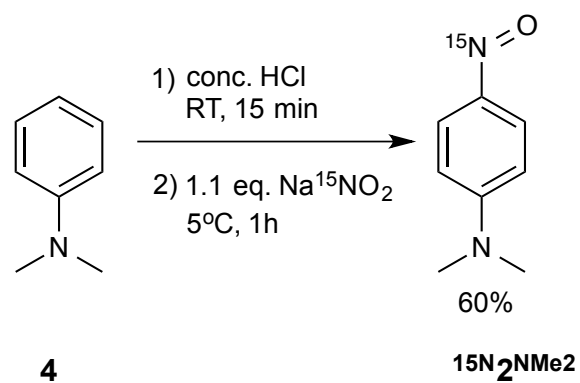

\section{4-bromo- ${ }^{15} \mathrm{~N}$-nitrosobenzene $\left({ }^{15 \mathrm{~N}} \mathbf{2}^{\mathrm{Br}}\right)$.}<smiles>CC(=O)Nc1ccccc1</smiles>

$15 \mathrm{~N}_{5}$

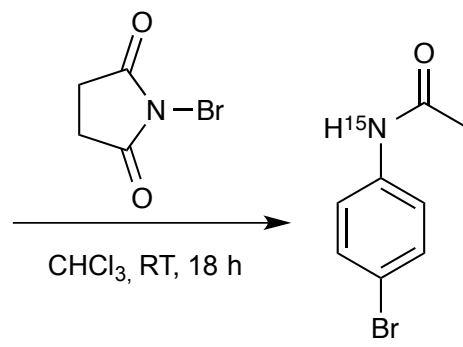

$94 \%$

${ }^{15} \mathrm{~N}_{6} \mathrm{Br}$
1) $6 \mathrm{M} \mathrm{HCl}, 2 \mathrm{~h}$

2) $1 \mathrm{M} \mathrm{NaOH}$ to $\mathrm{pH} 7$ 3) $\mathrm{NaHCO}_{3}$ to basic $\mathrm{pH}$

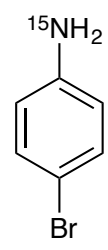

$87 \%$

$15 \mathrm{~N} 7 \mathrm{Br}$

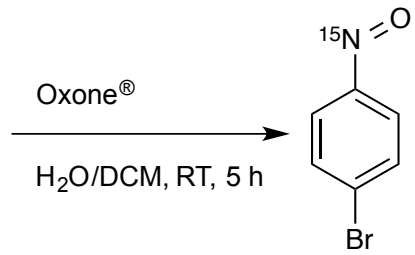

$80-90 \%$

${ }^{15 N} 6^{\mathrm{Br}}$. To a solution of $250 \mathrm{mg}$ of acetanilide- ${ }^{15} \mathrm{~N},{ }^{15 \mathrm{~N}} 5$, in chloroform was added 1.1 eq. of NBS as solid in portions at room temperature. After stirring for 18 hours, the reaction was quenched by addition of aqueous $\mathrm{Na}_{2} \mathrm{~S}_{2} \mathrm{O}_{3}(0.5 \mathrm{M})$ and stirred for one more hour at room temperature. The organic phase was separated, and the aqueous phase was extracted twice with chloroform. The combined organic layers were dried over $\mathrm{Na}_{2} \mathrm{SO}_{4}$, filtered and the solvent was removed by rotary evaporation to give an off-white solid. The solid was recrystallized from $\mathrm{CH}_{2} \mathrm{Cl}_{2}$ :hexanes (1:10) to yield white crystals of ${ }^{15 \mathrm{~N}} 6^{\mathrm{Br}}(94 \%)$.

${ }^{15 N} 7^{\mathrm{Br}}$. $1.6 \mathrm{mmol}$ of ${ }^{15 \mathrm{~N}} 6^{\mathrm{Br}}$ were placed in $10 \mathrm{~mL}$ of $6 \mathrm{M} \mathrm{HCl}$ and refluxed for 2-3 hours (followed by thin-layer chromatography, TLC, after micro-extraction with dichloromethane, eluent: DCM). Once the TLC indicates full conversion of the starting material, the acidity of the mixture was reduced by addition of $1 \mathrm{M} \mathrm{NaOH}$ in an ice batch (caution: monitor the inner temperature carefully to avoid uncontrolled), then followed by addition of $\mathrm{NaHCO}_{3}(\mathrm{aq})$ to basic $\mathrm{pH}$. The aqueous mixture was extracted by dichloromethane three times. The combined organic fractions were dried over sodium sulfate, filtered and the solvent was removed by rotary evaporation 
to yield and off-white solid. The product purified by recrystallization out of hexanes to yield ${ }^{15 N} 7^{\mathrm{Br}}$ as a white solid (87\%).

${ }^{15 \mathrm{~N}} 2^{\mathrm{Br}}$. ${ }^{3}$ To a solution of ${ }^{15 \mathrm{~N}} 7^{\mathrm{Br}}(1.2 \mathrm{mmol})$ in $20 \mathrm{~mL} \mathrm{CH} \mathrm{Cl}_{2}, 1.5 \mathrm{~g}$ of Oxone ${ }^{\circledR}$ dissolved in $20 \mathrm{~mL}$ of water was added at room temperature. The mixture was stirred vigorously for $5 \mathrm{~h}$. The reaction progress was monitored by TLC (eluent: $\mathrm{CH}_{2} \mathrm{Cl}_{2}$ ). Once the spot for starting material fainted, the organic layer was separated and washed with two portions of $1 \mathrm{M} \mathrm{HCl}$, then dried over sodium sulfate, filtered and the solvent was removed by rotary evaporation to yield ${ }^{15 N} 2^{X}$ as a yellow $(X=B r)$ solid $(80-90 \%)$. Note: the same procedure applied to the chloro derivative yielded mixtures of 2-chloronitrosobenzene and 4-chloronitrosobenzene and was not pursued further.

${ }^{15} \mathrm{~N}$-nitrosobenzene $\left({ }^{15 \mathrm{~N}} 2^{\mathrm{H}}\right)$. This compound was prepared in $88 \%$ yield as for the $\mathrm{Cl}$ and $\mathrm{Br}$ derivatives from commercial ${ }^{15} \mathrm{~N}$-aniline. ${ }^{3}$

\section{IR data and vibrational DFT calculations}

\section{a) $2^{\mathrm{R}}$ compounds}

Table S2. Vibrational data for $\mathbf{2}^{\mathrm{R}}$ species $\left(\mathrm{R}=\mathrm{NMe}_{2}, \mathrm{H}\right.$ and $\left.\mathrm{Br}\right) .^{a}$

\begin{tabular}{lllll}
\hline Compound & & $\boldsymbol{v}(\mathbf{N O})$ & $\boldsymbol{v}(\mathrm{CN})$ & $\boldsymbol{\delta}$ (CNO) \\
\hline $\mathbf{2}^{\text {NMe2 } b}$ & Calculated: & $1537(7), 1483(9), 1450(6)$ & $1211(5), 1110(13)$ & $830(9), 727(5)$ \\
& Experimental: & $1549(8), 1365(12), 1340(19), 1304(14)$ & $1235(15), 1129(28)$ & $837(9), 729(4)$ \\
$\mathbf{2}^{\mathbf{H c}}$ & Calculated: & $1336(22), 1321(25), 1291(14)$ & $1146(8), 1122(8)^{e}$ & $930(12)$ \\
& Experimental: & $1404(26), 1388(27)$ & $1189(7), 1168(5)^{e}$ & $948(12)$ \\
$\mathbf{2}^{\text {Br d }}$ & Calculated: & $1296(6), 1275(17)$ & $1141(5)$ & $831(11)$ \\
& Experimental: & $1286(4), 1256(24)$ & $1186(13)$ & $856(12)$ \\
\hline
\end{tabular}

${ }^{a} v\left({ }^{14} \mathrm{~N}\right)\left(\Delta\left({ }^{14} \mathrm{~N}-{ }^{15} \mathrm{~N}\right)\right) / \mathrm{cm}^{-1}$. More details in the Figures below. The IR data for $\mathbf{2}^{\mathrm{NO2}}$ is given in the Supporting Information of reference $\$^{1} .{ }^{b}$ Monomeric species. ${ }^{c}$ Syn dimer. ${ }^{d}$ Anti dimer. ${ }^{e}$ This mode also involves an NN stretch. 

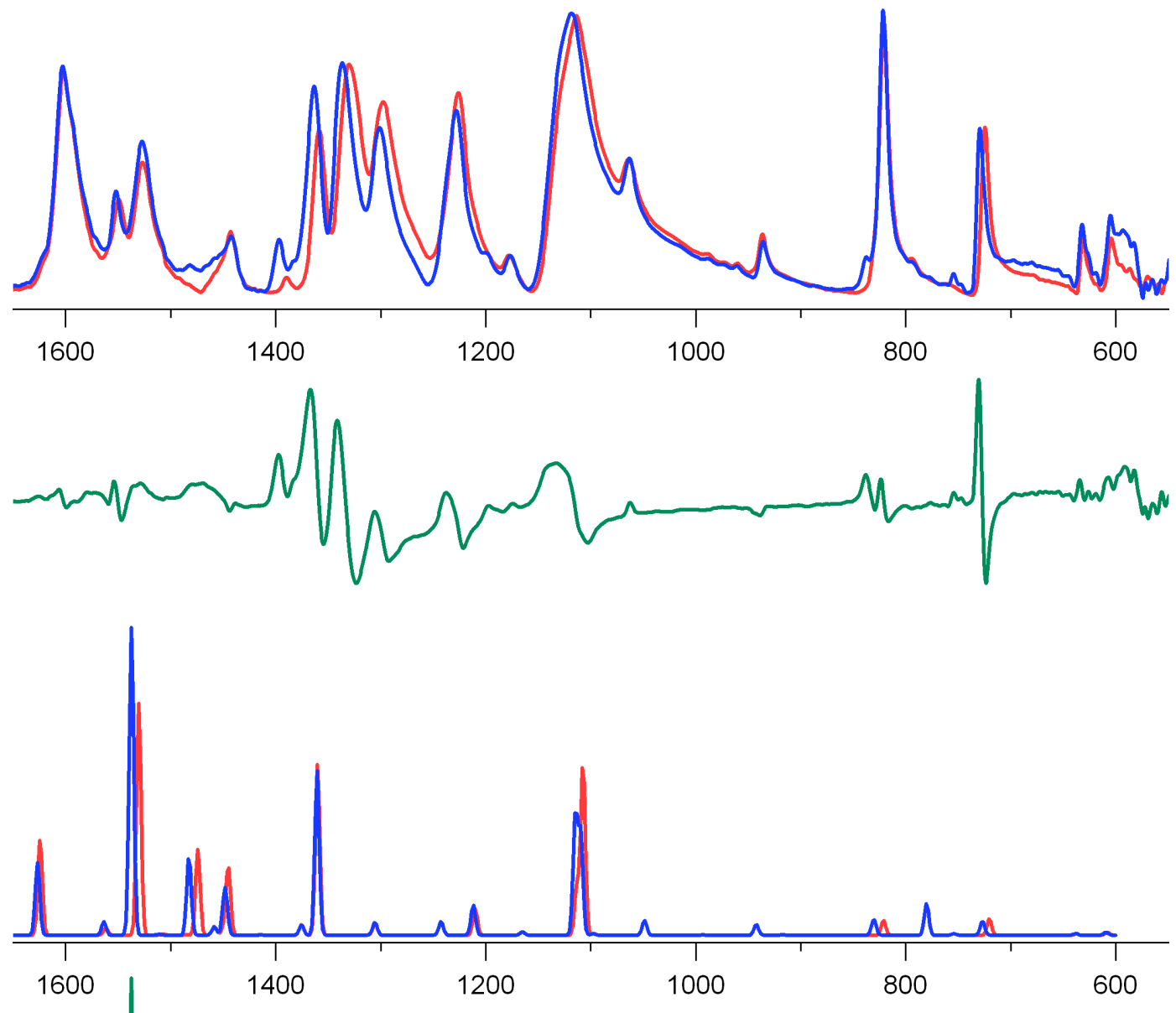

Figure S1. Experimental (top) and computational (bottom, see below for details) IR spectra of solid $\mathbf{2}^{\text {NMe2 }}$ with ${ }^{14} \mathrm{~N}$ (blue) and ${ }^{15} \mathrm{~N}$ (red) and difference spectrum (green). Isotopic labeling on the NO moiety only. 

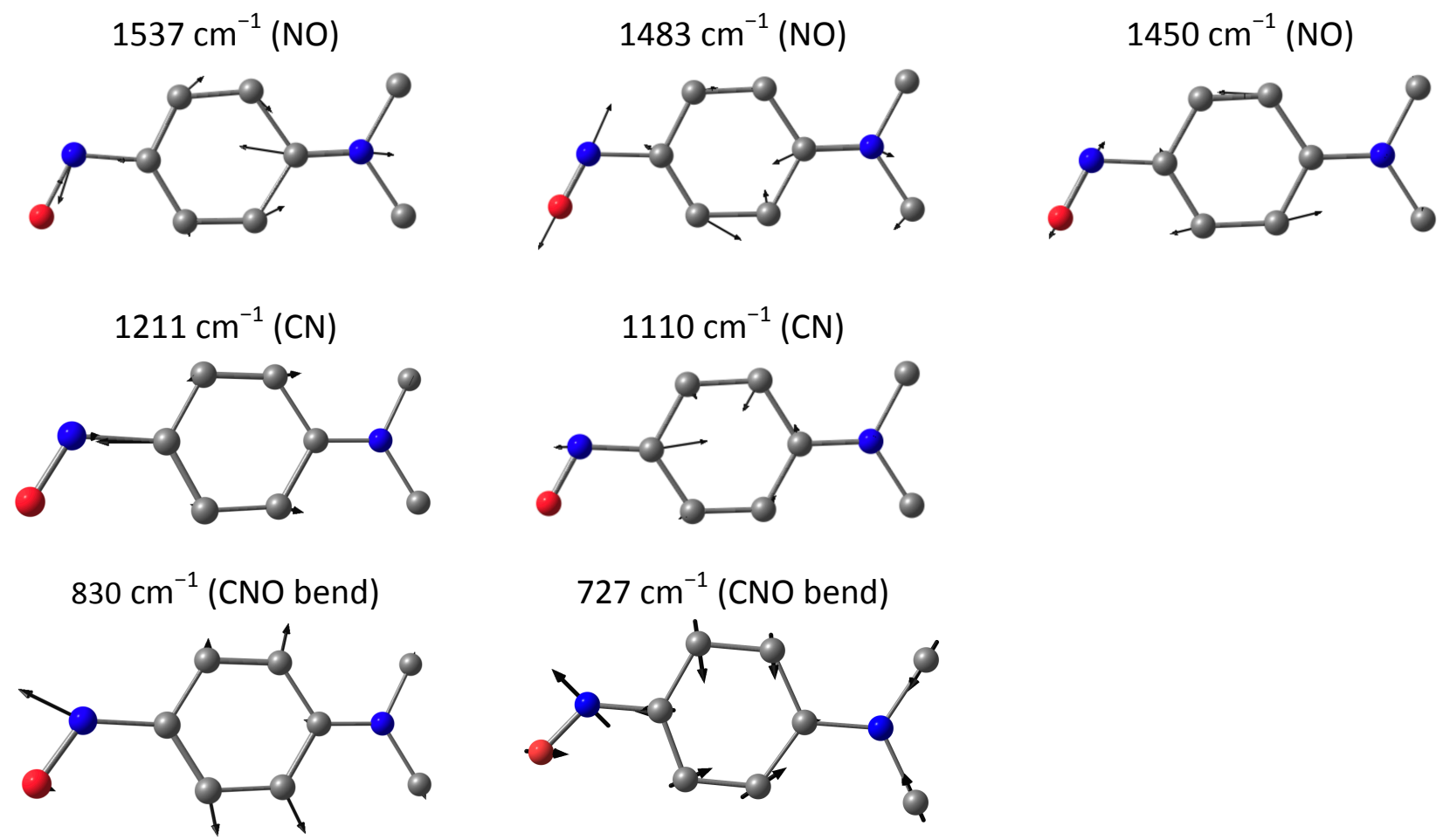

Figure S2. Selected vibrational normal modes for $\mathbf{2}^{\text {NMe2 }}$. 

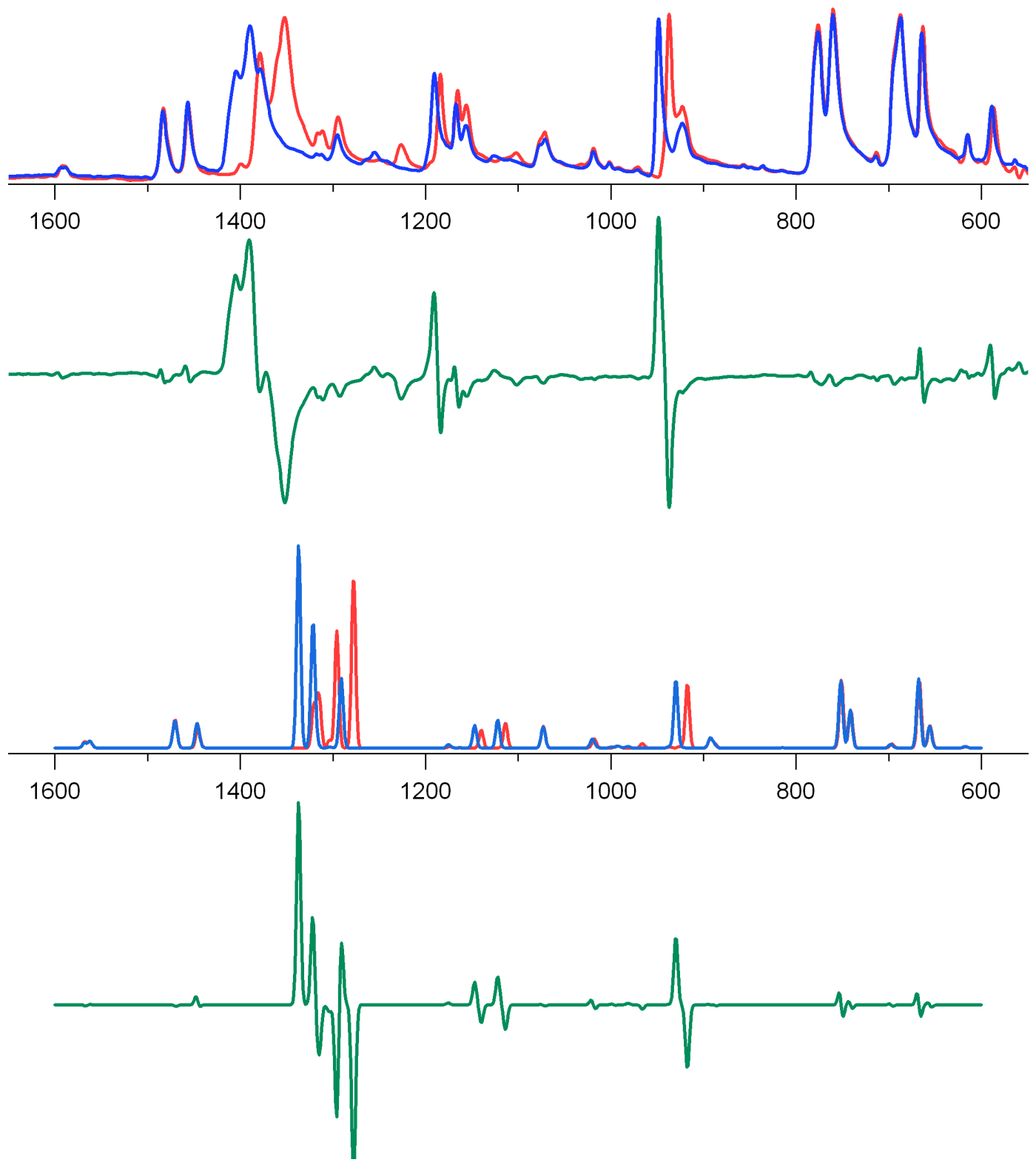

Figure S3. Experimental (top) and computational (bottom, see below for details) IR spectra of solid $\mathbf{2}^{\mathrm{H}}$ with ${ }^{14} \mathrm{~N}$ (blue) and ${ }^{15} \mathrm{~N}$ (red) and difference spectrum (green). 

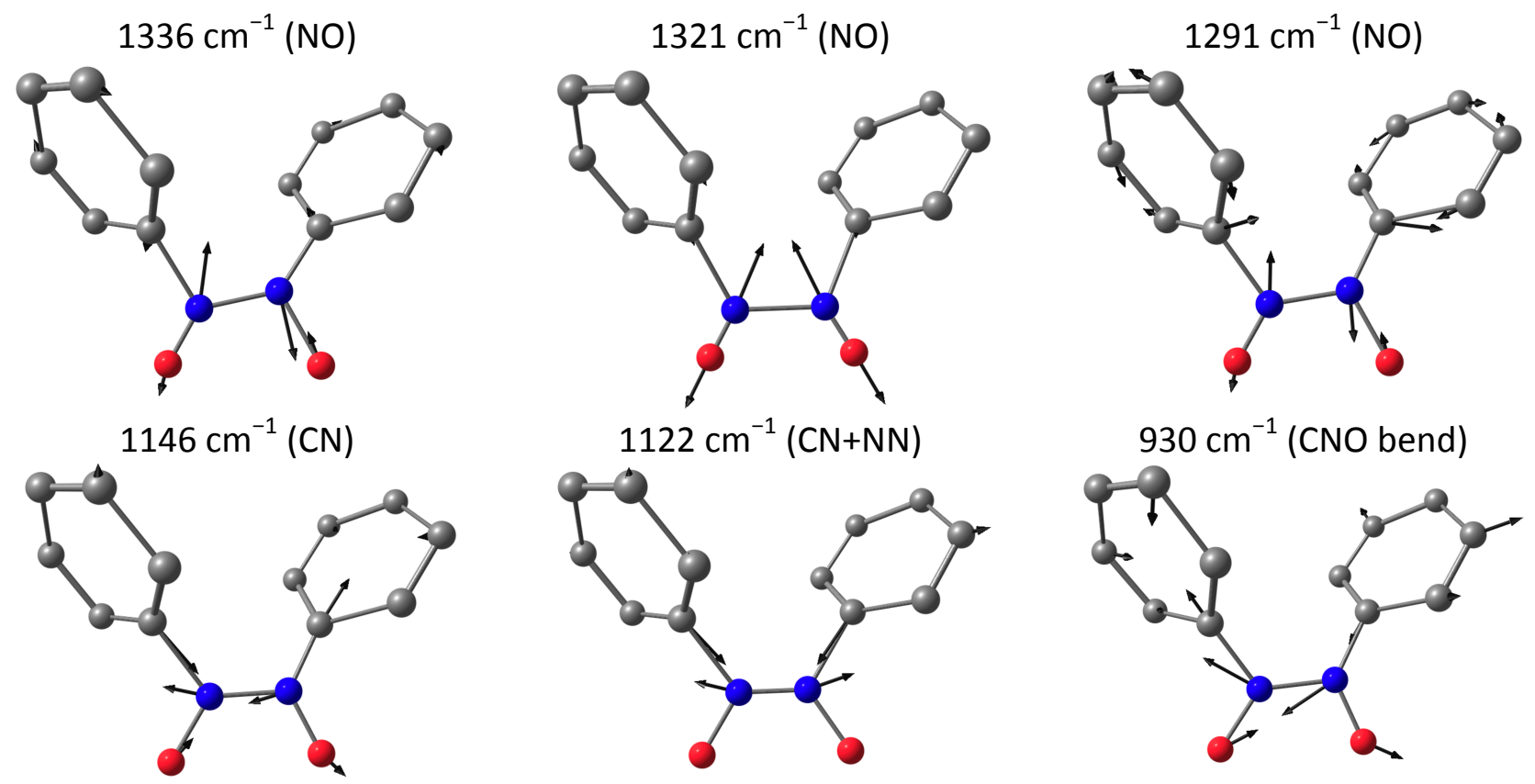

Figure S4. Selected vibrational normal modes for $\mathbf{2}^{\mathrm{H}}$. 

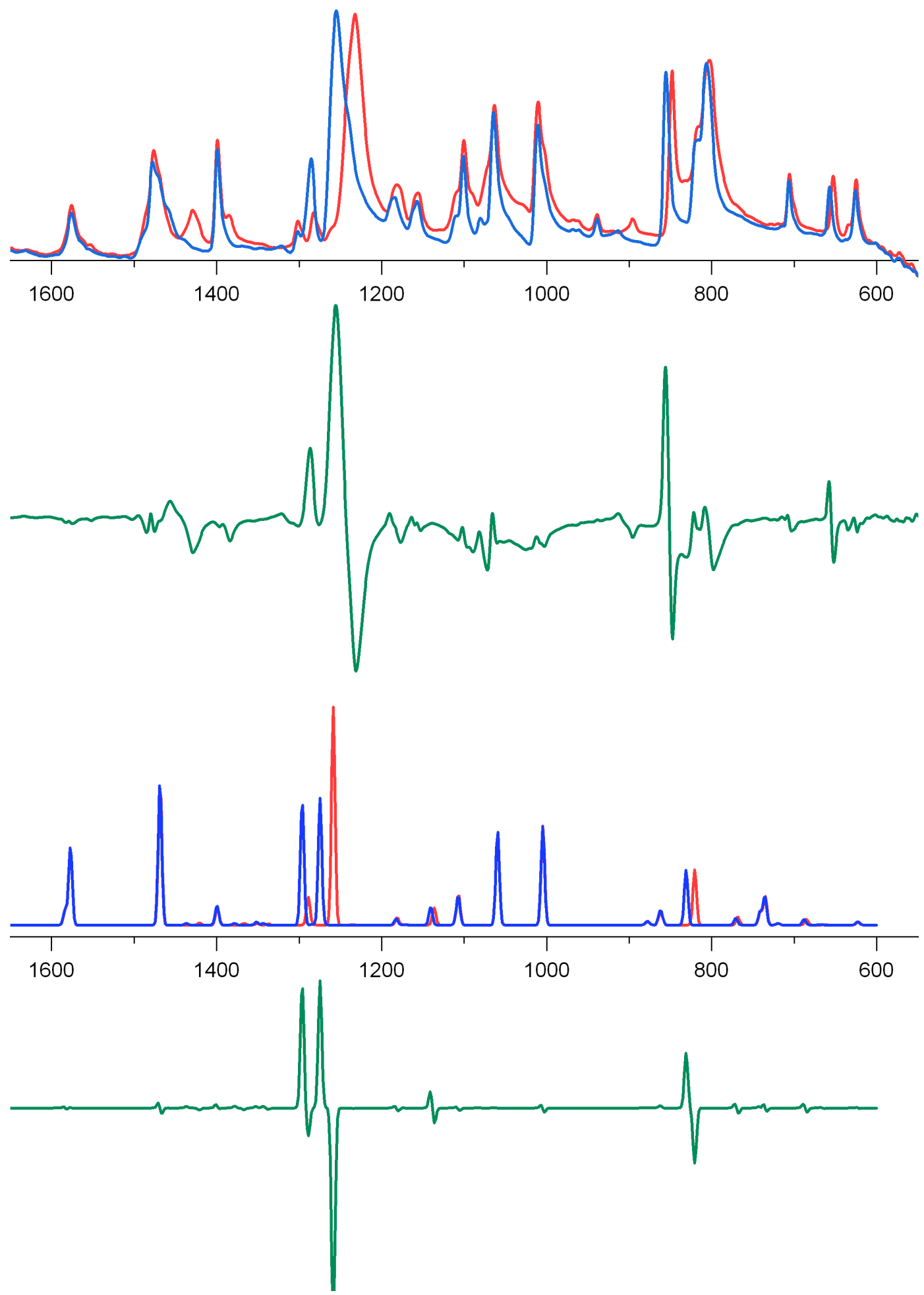

Figure S5. Experimental (top) and computational (bottom, see below for details) IR spectra of solid $\mathbf{2}^{\mathrm{Br}}$ with ${ }^{14} \mathrm{~N}$ (blue) and ${ }^{15} \mathrm{~N}$ (red) and difference spectrum (green). 

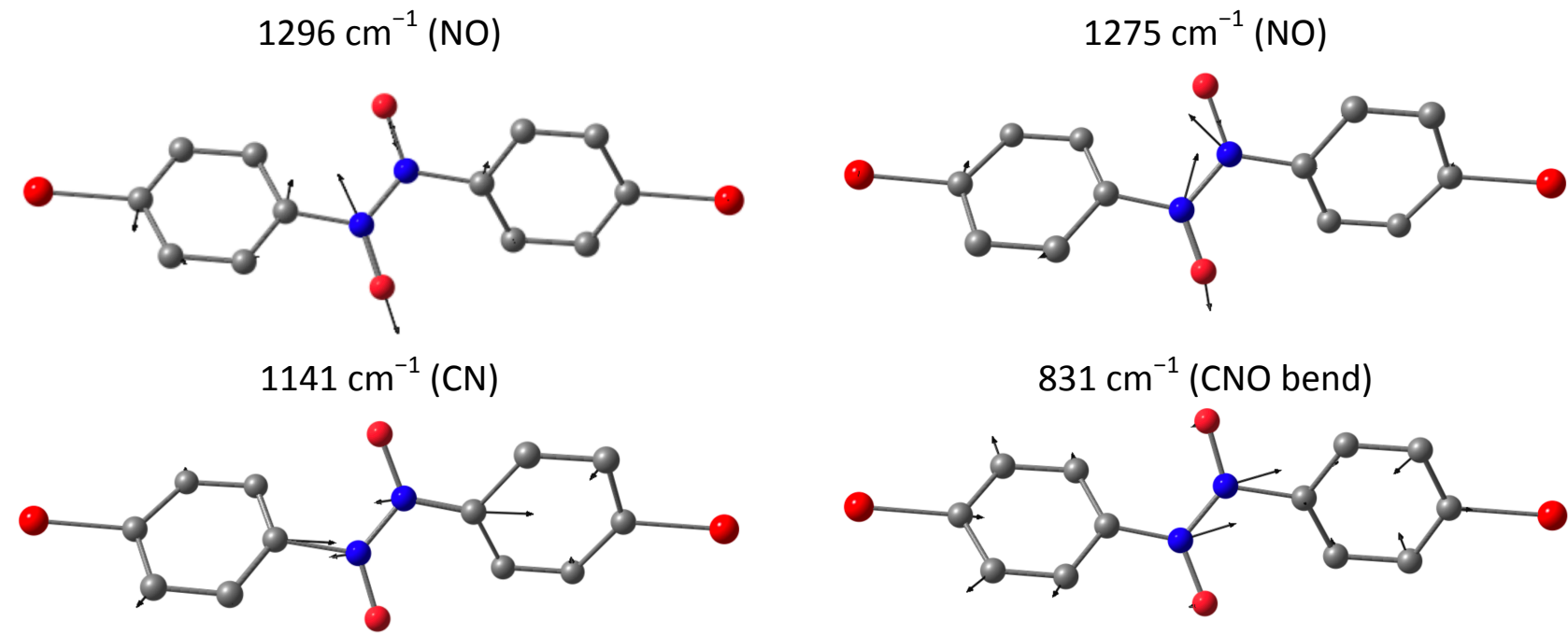

Figure S6. Selected vibrational normal modes for $\mathbf{2}^{\mathrm{Br}}$.

\section{b) $3^{\mathrm{R}}$ complexes}

Table S3. Vibrational data for $3^{\mathrm{R}}$ species $\left(\mathrm{R}=\mathrm{NMe}_{2}, \mathrm{H}, \mathrm{Br}\right.$ and $\left.\mathrm{NO}_{2}\right){ }^{a}$

\begin{tabular}{lllll}
\hline Compound & & $\boldsymbol{v}(\mathrm{NO})$ & $\boldsymbol{v}(\mathrm{CN})$ & $\boldsymbol{\delta}(\mathrm{CNO})$ \\
\hline $\mathbf{3}^{\mathrm{NMe2}}$ & Calculated: & $1418(20), 1382(3), 1362(4)$ & $1260(5), 1152(4)$ & $873(14) 740(4)$ \\
& Experimental: & $1392(14), 1315(6)$ & $1287(8), 1236(33)$ & $875(10), 738(14)$ \\
$\mathbf{3}^{\mathrm{H}_{\mathbf{1}}}$ & Calculated: & $1178(5), 1170(20)$ & $1133(4), 1195(9)$ & $838(14), 653(4)$ \\
& Experimental: & $1162(10), 1133(23)$ & $1066(8)$ & $835(20), 652(15)$ \\
$\mathbf{3}^{\mathrm{Br}}$ & Calculated: & $1258(5)$ & $1131(10), 1125(6)$ & $819(9), 669(7)$ \\
& Experimental: & $1226(6)$ & $1123(14), 1103(6), 1091(4)$ & $826(5), 817(7), 668(16)$ \\
\hline
\end{tabular}

${ }^{a} v\left({ }^{14} \mathrm{~N}\right)\left(\Delta\left({ }^{14} \mathrm{~N}-{ }^{15} \mathrm{~N}\right)\right) / \mathrm{cm}^{-1}$. More details in the Figures below. The IR data for $3^{\mathrm{NO2}}$ is given in the Supporting Information of reference $\$^{1} .{ }^{b}$ This mode includes some degree of NO stretch as well, and is not intense. 

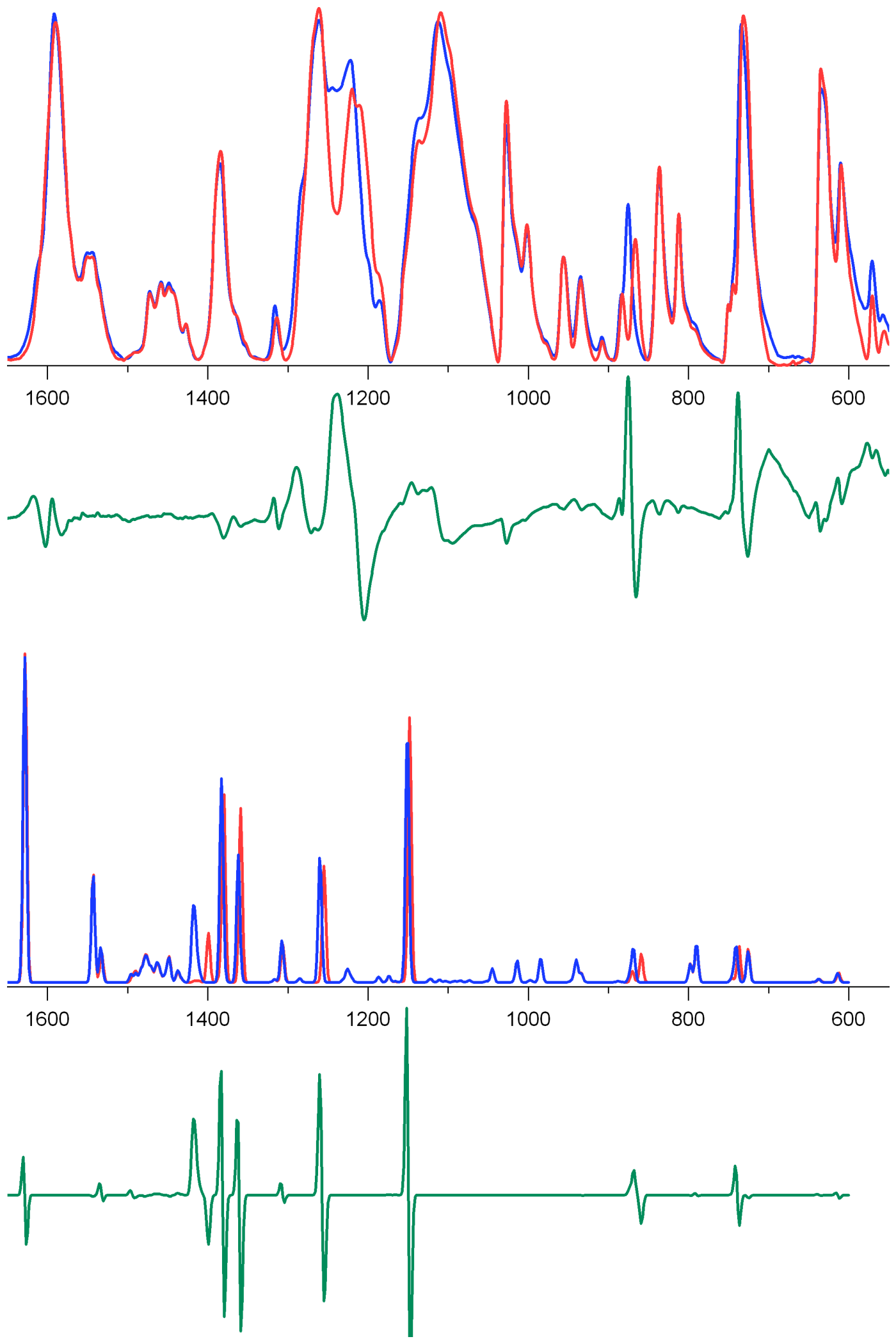

Figure S7. Experimental (top) and computational (bottom, see below for details) IR spectrum of solid $3^{\mathrm{NMe2}}$ with ${ }^{14} \mathrm{~N}$ (blue) and ${ }^{15} \mathrm{~N}$ (red) and difference spectrum (green). Isotopic labeling on the NO moiety only. Note that the NO stretch is difficult to see experimentally because of the dimeric structure in the solidstate, with individual complexes related by an inversion center. 

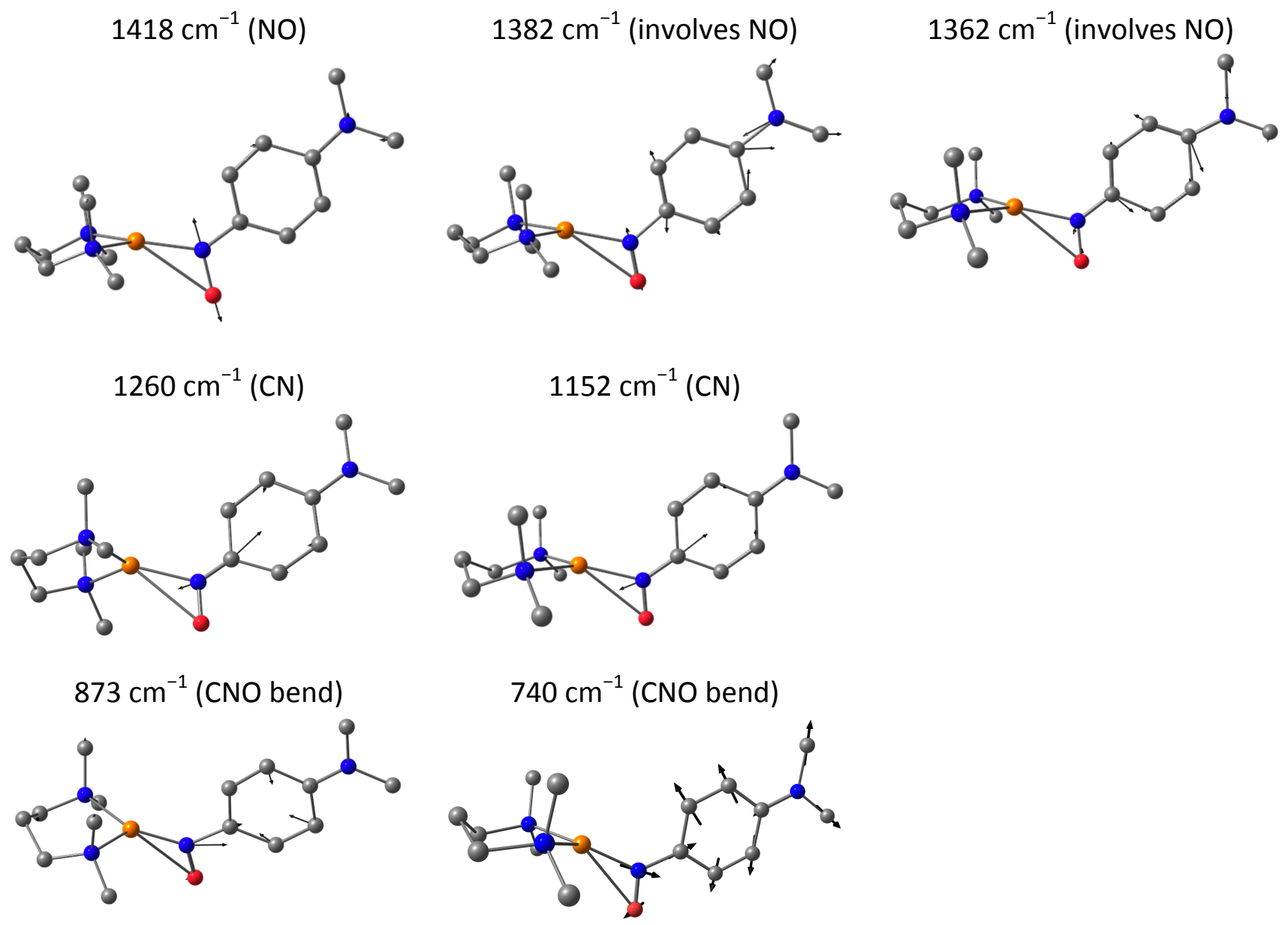

Figure S8. Selected vibrational normal modes for $3^{\text {NMe2 }}$. 

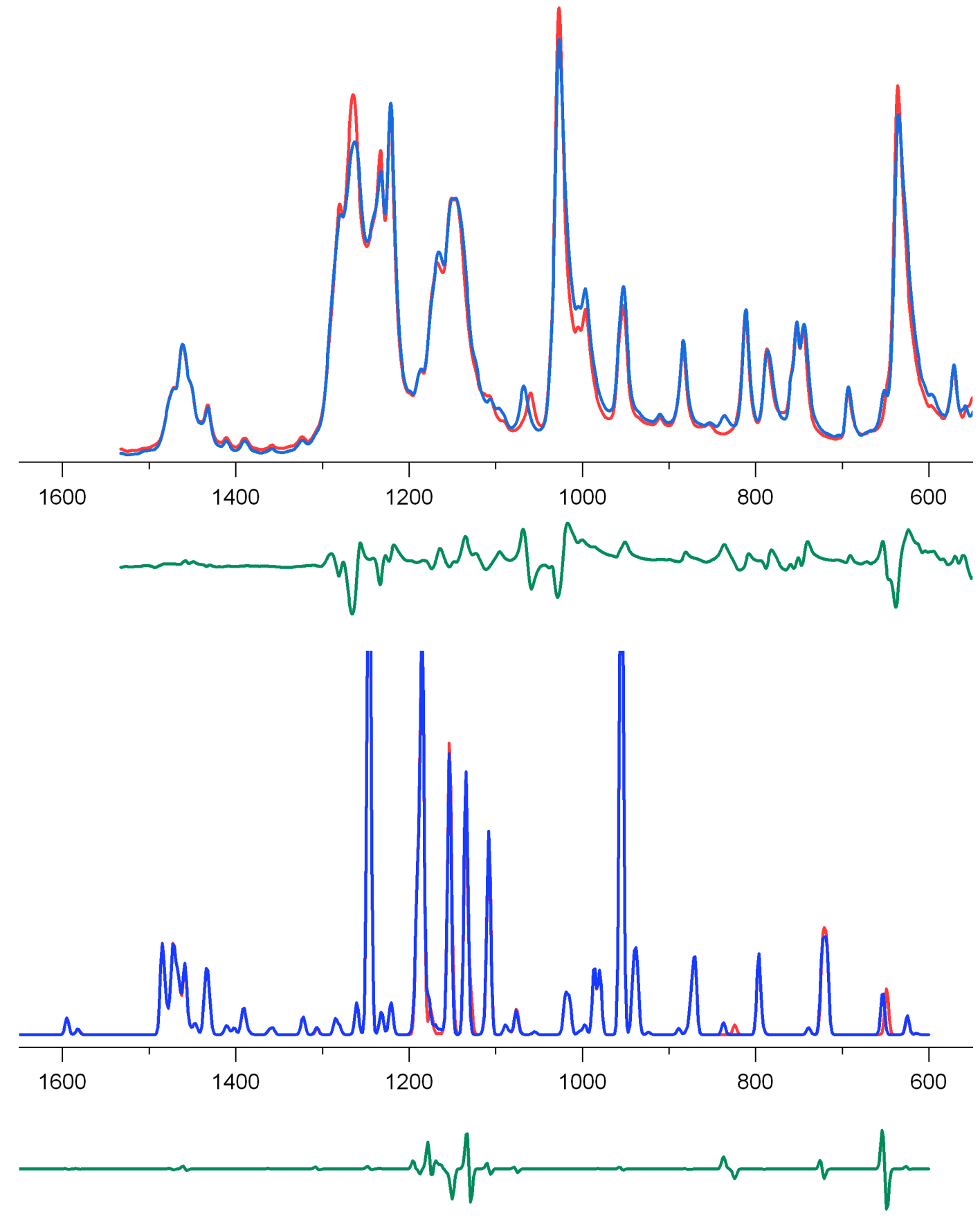

Figure S9. Experimental (top) and computational (bottom, see below for details) IR spectrum of solid $\mathbf{3}^{\mathrm{H}_{\mathbf{I}}}$ (and a minor quantity of $3^{\mathrm{H}}$ ) with ${ }^{14} \mathrm{~N}$ (blue) and ${ }^{15} \mathrm{~N}$ (red) and difference spectrum (green). Isotopic labeling on the NO moiety only. 

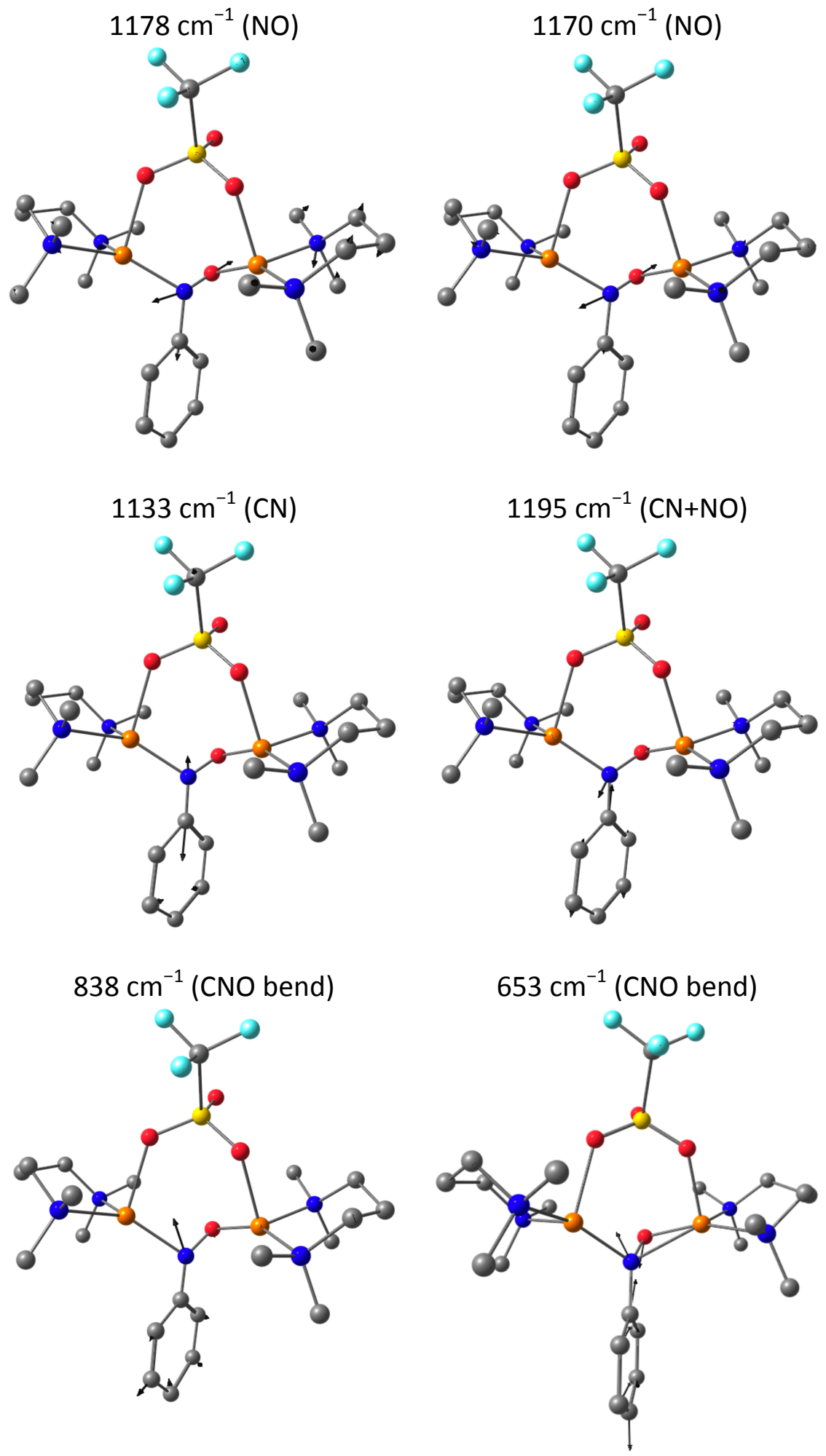

Figure S10. Selected vibrational normal modes for $\mathbf{3}^{\mathrm{H}_{1}}$. 

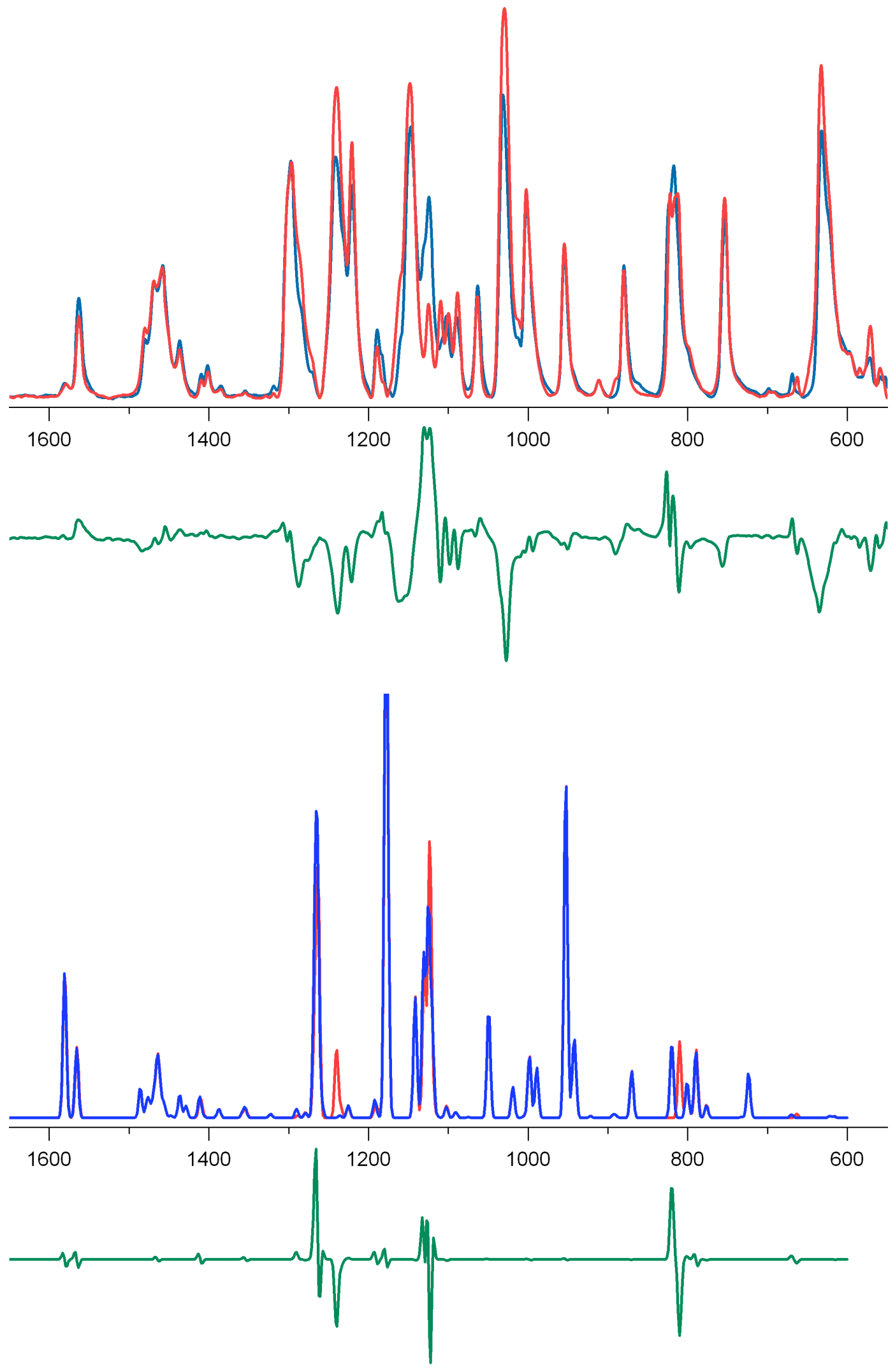

Figure S11. Experimental (top) and computational (bottom, see below for details) IR spectra of solid $\mathbf{3}^{\mathrm{Br}}$ with ${ }^{14} \mathrm{~N}$ (blue) and ${ }^{15} \mathrm{~N}$ (red) and difference spectrum (green). Isotopic labeling on the NO moiety only. 

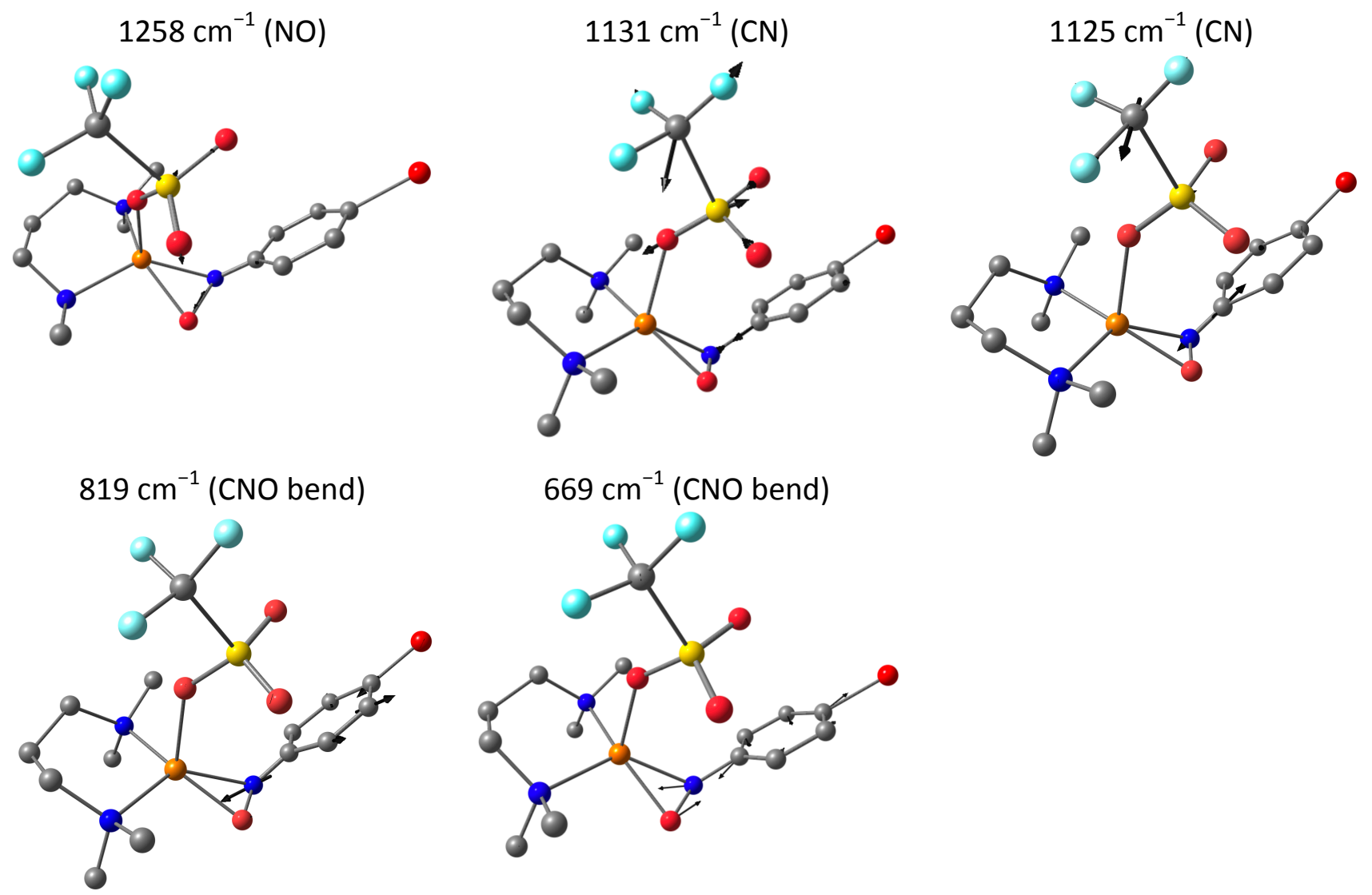

Figure S12. Selected vibrational normal modes for $3^{\mathrm{Br}}$. 


\section{Electronic structure calculations}
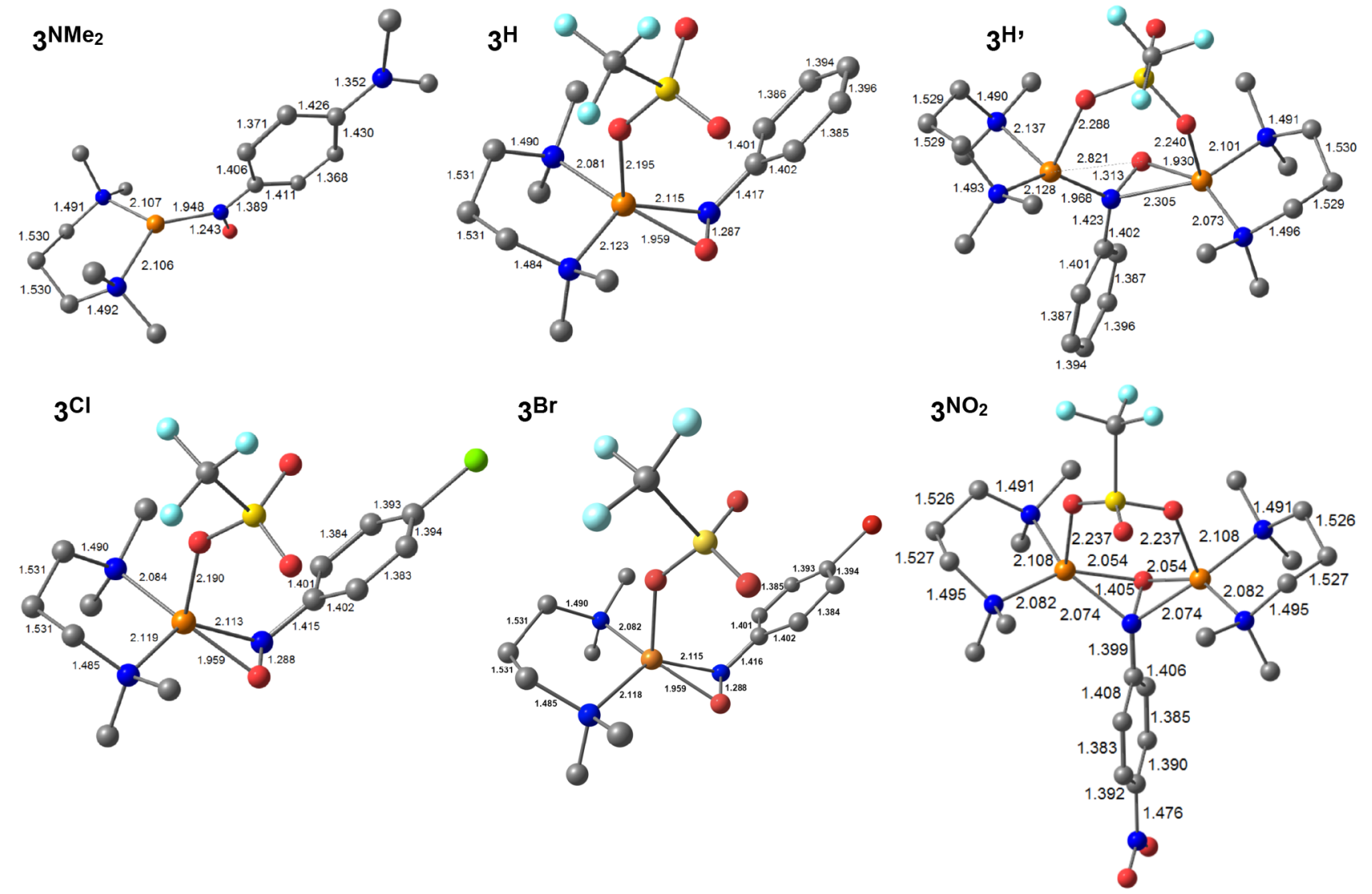

Figure S13. DFT-optimized geometries of $3^{\mathrm{R}}$ complexes $\left(\mathrm{R}=\mathrm{NMe}_{2}, \mathrm{H}, \mathrm{Cl}, \mathrm{Br}\right.$ and $\left.\mathrm{NO}_{2}\right)$. For $\mathrm{R}=\mathrm{H}$, both the mononuclear $\left(3^{\mathrm{H}}\right)$ and dinuclear $\left(3^{\mathrm{H}_{\mathbf{H}}}\right)$ structures were considered. 


\section{UV-vis data and TD-DFT-calculations}

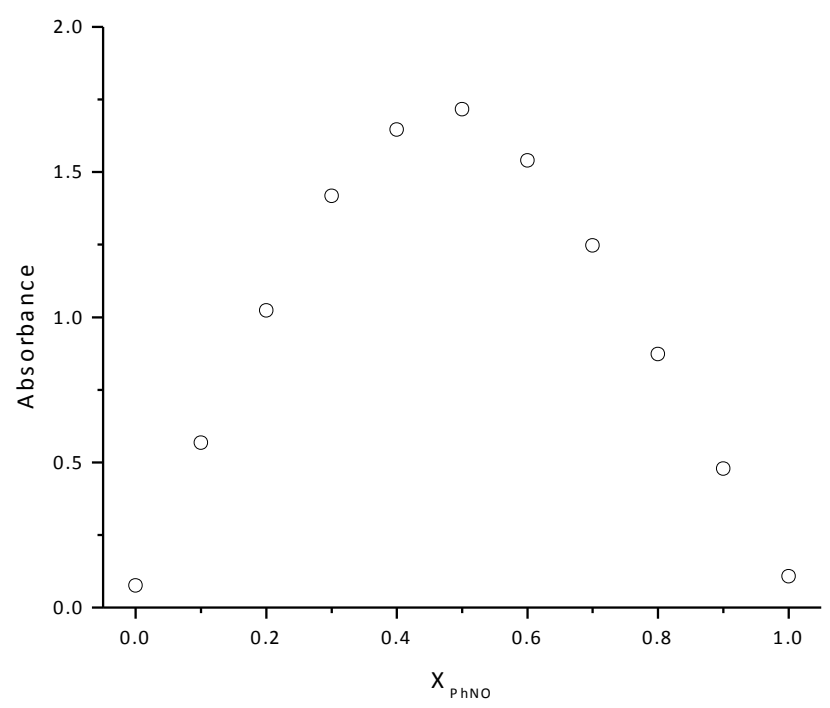

Figure S14. Job plot between $\mathrm{TMPDCu}^{+}, \mathbf{1}$, and $\mathrm{PhNO}, \mathbf{2}^{\mathrm{H}}$ in $\mathrm{THF}$ at $25^{\circ} \mathrm{C}$ with $\left[\mathrm{TMPDCu}^{+}\right]+[\mathrm{PhNO}]=1.0$ $\mathrm{mM}$. Solutions were prepared in the glovebox by mixing (1-x) TMPD, $(1-x)$ [ $\left.\mathrm{Cu}^{\prime}\left(\mathrm{CH}_{3} \mathrm{CN}\right)_{4}\right](\mathrm{TfO})$ and $x$ PhNO from appropriate stock solutions, then bringing the total volume to $5 \mathrm{~mL}$ and measuring the absorbance at $610 \mathrm{~nm}$ on the spectrophotometer (pathlength $1 \mathrm{~cm}$ ). The dissymmetry of the data suggests the presence of the dinuclear $3^{\mathrm{H}_{1}}$ species at low $x$ values ("rounding" of the curve).
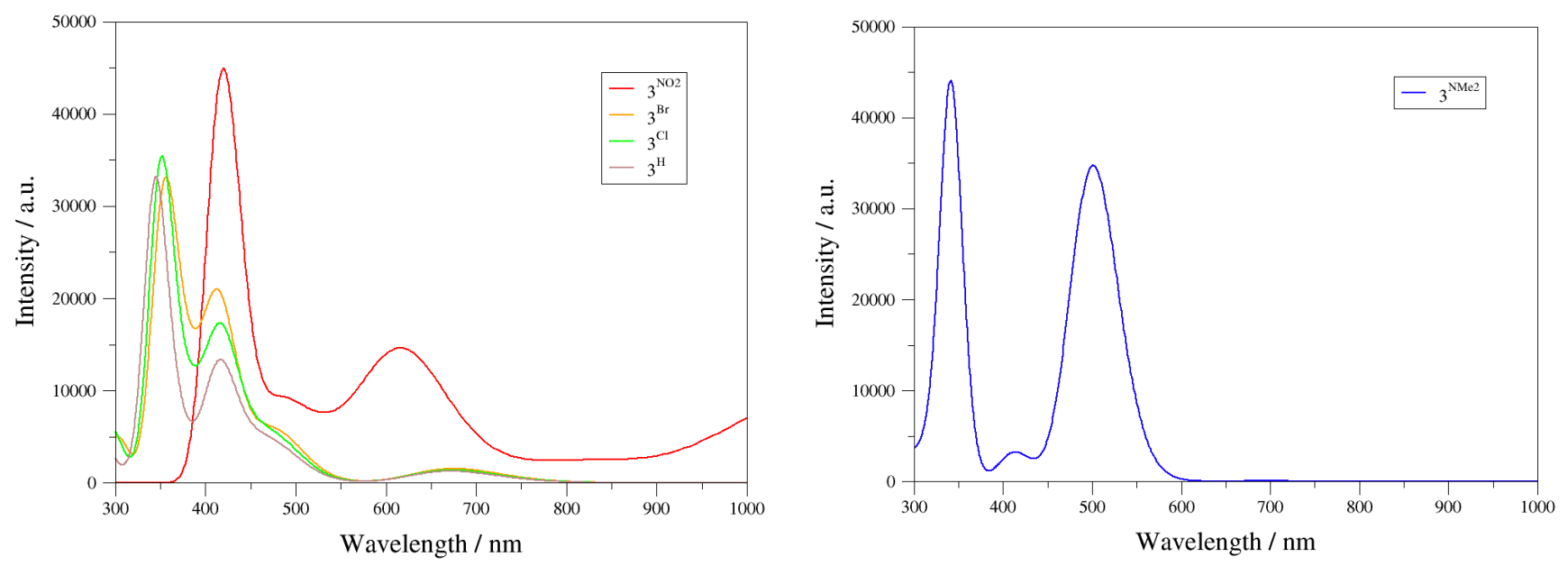

Figure S15. Theoretical fit of the UV-vis spectra of $3^{\mathrm{H}}, 3^{\mathrm{Cl}}, \mathbf{3}^{\mathrm{Br}}$ and $3^{\mathrm{NO2}}$ (left) and $3^{\mathrm{NMe2}}$ (right)

Table S4. Calculated electronic transitions of $3^{\mathrm{NMe2}}$.

\begin{tabular}{lllll}
\hline Transition & $\lambda^{\text {calc }}(\mathrm{nm})$ & $f^{\text {calc }}(\mathrm{nm})$ & Assignment & $\lambda^{\text {expt }} / \mathbf{n m}(\varepsilon)$ \\
\hline 1 & 694 & 0.001 & (ML)-LCT & $690(2.3)$ \\
2 & 501 & 0.396 & MLCT & $538(34.7)$ \\
3 & 341 & 0.497 & LLCT & $426(32.8)$ \\
\hline
\end{tabular}


Transition 1

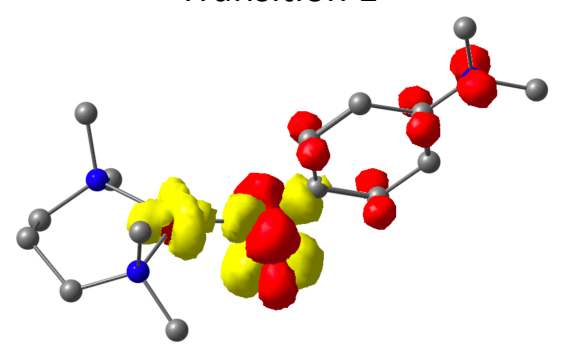

Transition 2

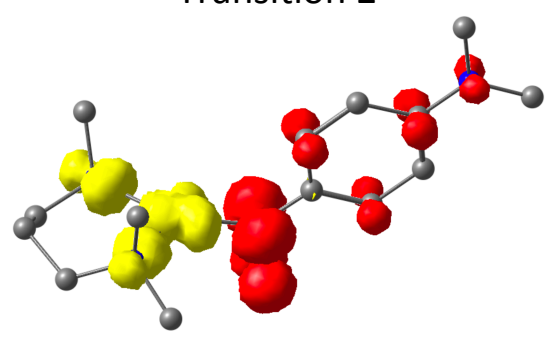

Transition 3

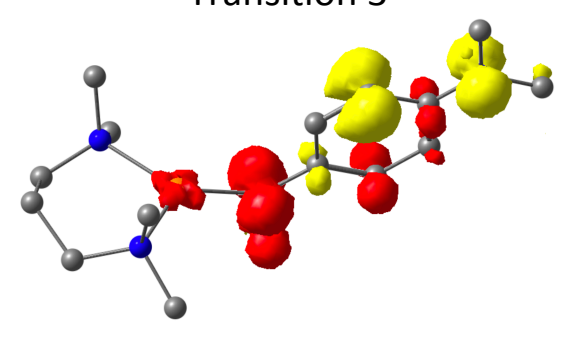

Figure S16. Difference electron densities sketch of transitions 1-3 for $\mathbf{3}^{\mathrm{NMe2}}$.

Table S5. Calculated electronic transitions of $\mathbf{3}^{\mathbf{H}}$.

\begin{tabular}{lllll}
\hline Transition & $\lambda^{\text {calc }}(\mathbf{n m})$ & $f^{\text {calc }}(\mathbf{n m})$ & Assignment & $\lambda^{\text {expt }} / \mathbf{n m}(\varepsilon)$ \\
\hline 1 & 672 & 0.014 & $\mathrm{ML}(\mathrm{ML}) \mathrm{CT}$ & $609(1.9)$ \\
2 & 415 & 0.135 & $\mathrm{MLCT}$ & $338(7.4)$ \\
3 & 346 & 0.339 & $(\mathrm{ML}) \mathrm{LCT}$ & $313(8.0)$ \\
\hline
\end{tabular}

Transition 1

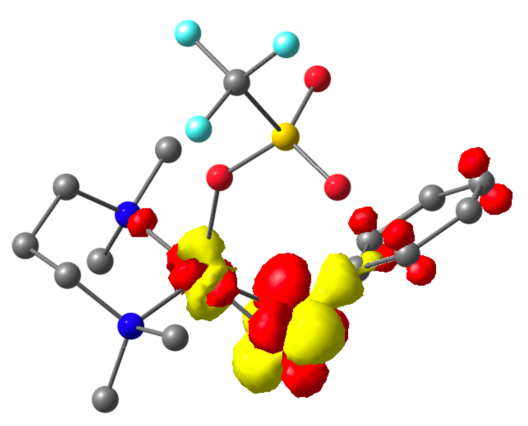

Transition 2

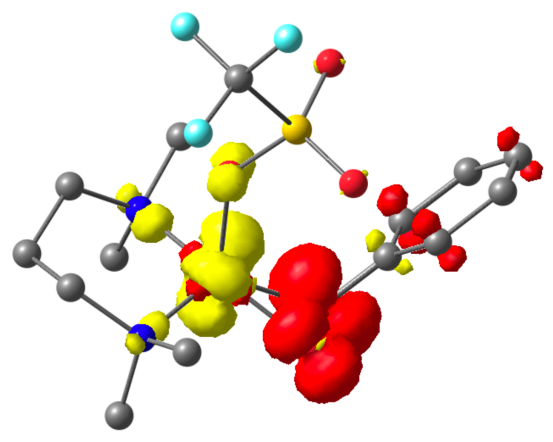

Transition 3

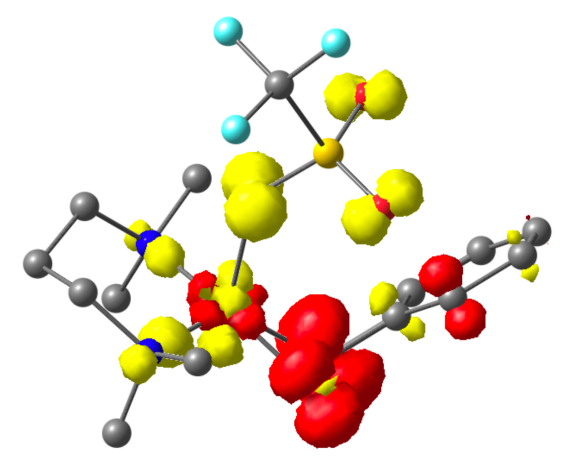

Figure S17. Difference electron densities sketch of transitions 1-3 for $\mathbf{3}^{\mathrm{H}}$.

Table S6. Calculated electronic transitions of $\mathbf{3}^{\mathrm{Cl}}$.

\begin{tabular}{lllll}
\hline Transition & $\lambda^{\text {calc }}(\mathbf{n m})$ & $f^{\text {calc }}(\mathbf{n m})$ & Assignment & $\lambda^{\text {expt }} / \mathbf{n m}(\varepsilon)$ \\
\hline 1 & 673 & 0.015 & ML(ML)CT & $614(1.2)$ \\
2 & 418 & 0.167 & MLCT & $350(7.3)$ \\
3 & 352 & 0.336 & $(\mathrm{ML})$ LCT & $319(10.4)$ \\
\hline
\end{tabular}



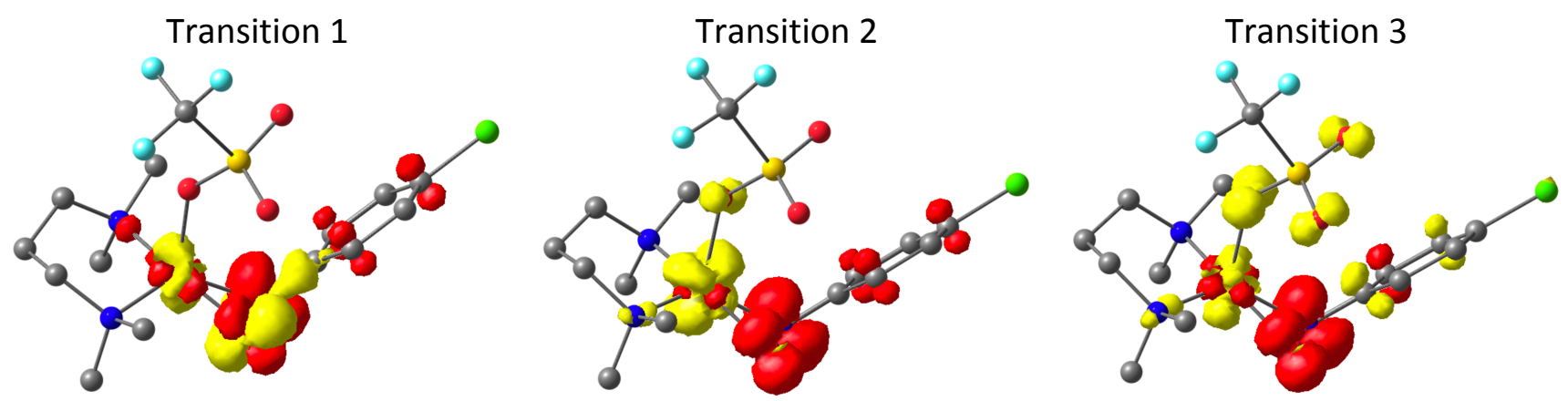

Figure S18. Difference electron densities sketch of transitions 1-3 for $3^{\mathrm{Cl}}$.

Table S7. Calculated electronic transitions of $\mathbf{3}^{\mathrm{Br}}$.

\begin{tabular}{lllll}
\hline Transition & $\lambda^{\text {calc }}(\mathrm{nm})$ & $f^{\text {calc }}(\mathrm{nm})$ & Assignment & $\lambda^{\text {expt }} / \mathbf{n m}(\varepsilon)$ \\
\hline 1 & 675 & 0.017 & ML(ML)CT & $614(1.2)$ \\
2 & 415 & 0.207 & MLCT & $350(8.2)$ \\
3 & 355 & 0.300 & $(\mathrm{ML})$ LCT & $325(10.4)$ \\
\hline
\end{tabular}
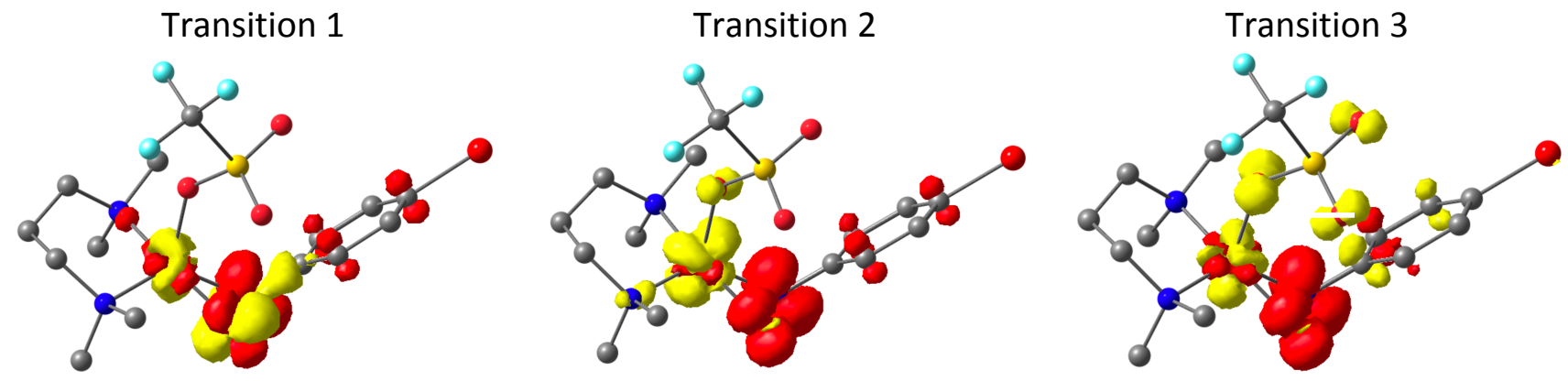

Figure S19. Difference electron densities sketch of transitions 1-3 for $3^{\mathrm{Br}}$.

Table S8. Calculated electronic transitions of $3^{\mathrm{NO2}}$.

\begin{tabular}{lllll}
\hline Transition & $\lambda^{\text {calc }}(\mathrm{nm})$ & $\boldsymbol{f}^{\text {calc }}(\mathrm{nm})$ & Assignment & $\lambda^{\text {expt }} / \mathrm{nm}(\varepsilon)$ \\
\hline 1 & 664 & 0.126 & MLCT & $644(1.5)$ \\
2 & 418 & 0.272 & MLCT & $345(19.4)$ \\
\hline
\end{tabular}



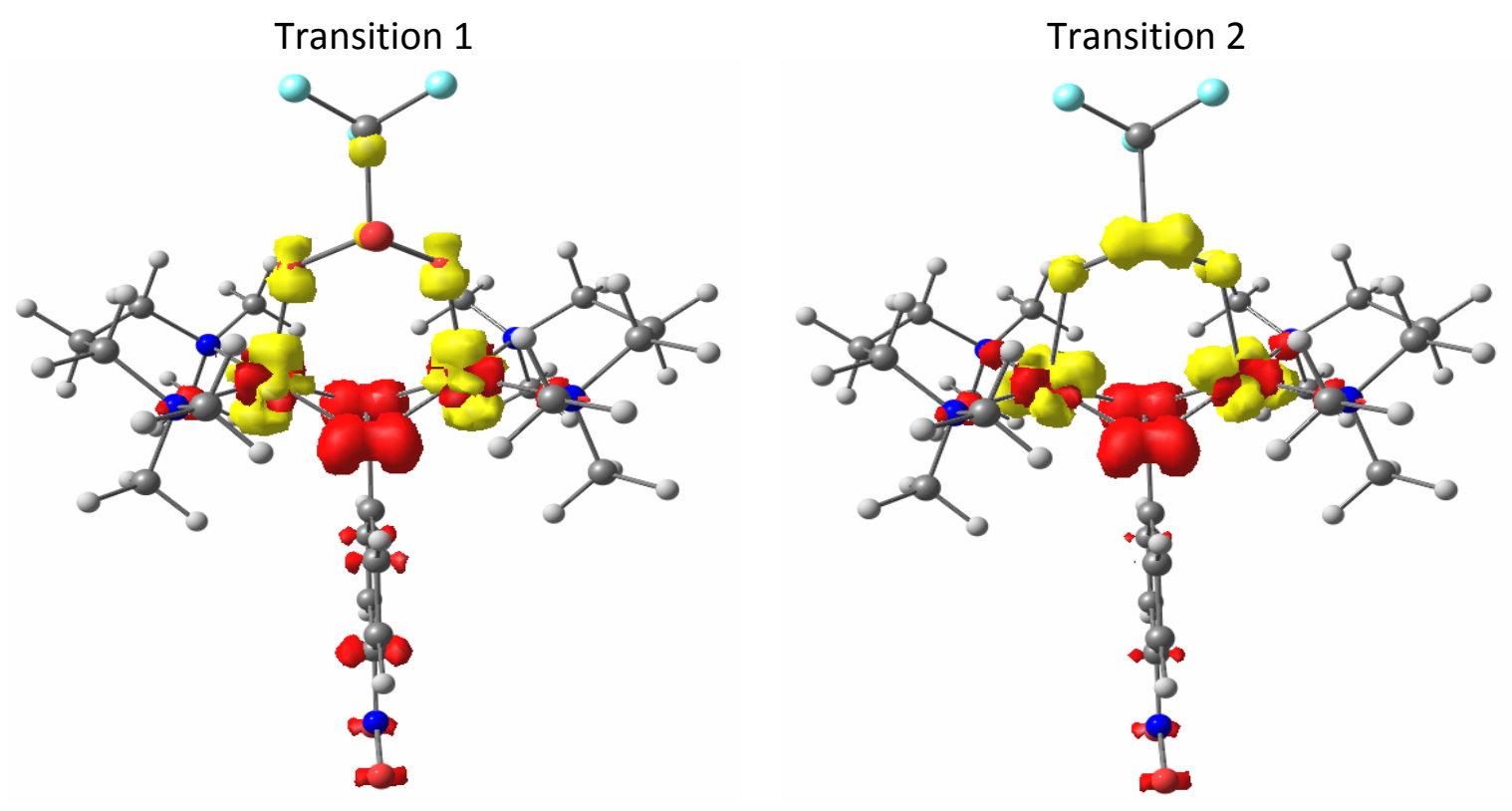

Figure S2O. Difference electron densities sketch of transitions 1-2 for $3^{\mathrm{NO2}}$. 


\section{Electrochemistry}

\section{a) CVs of $2^{R}$ ligands}

(a)

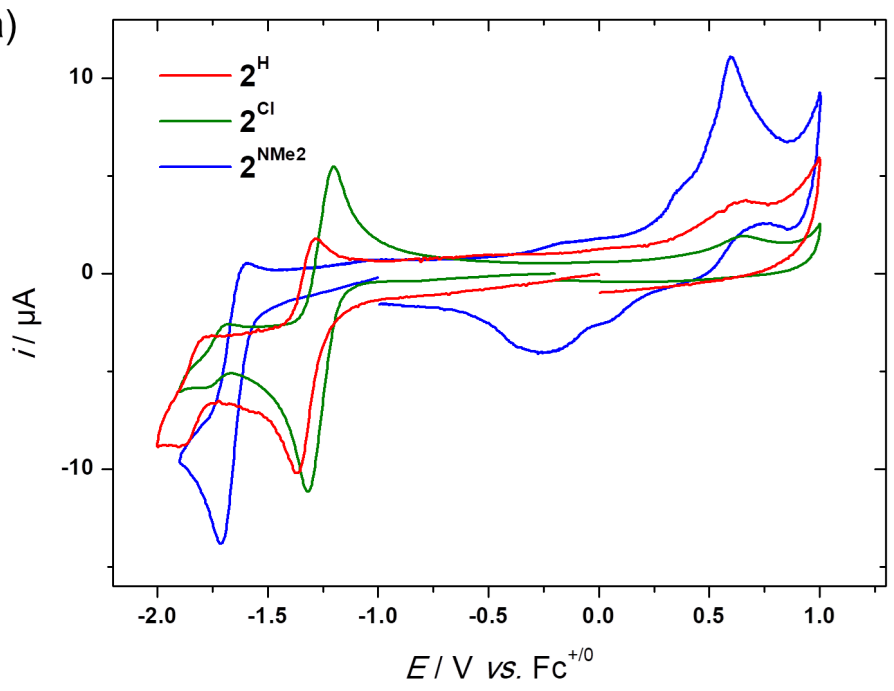

(b)

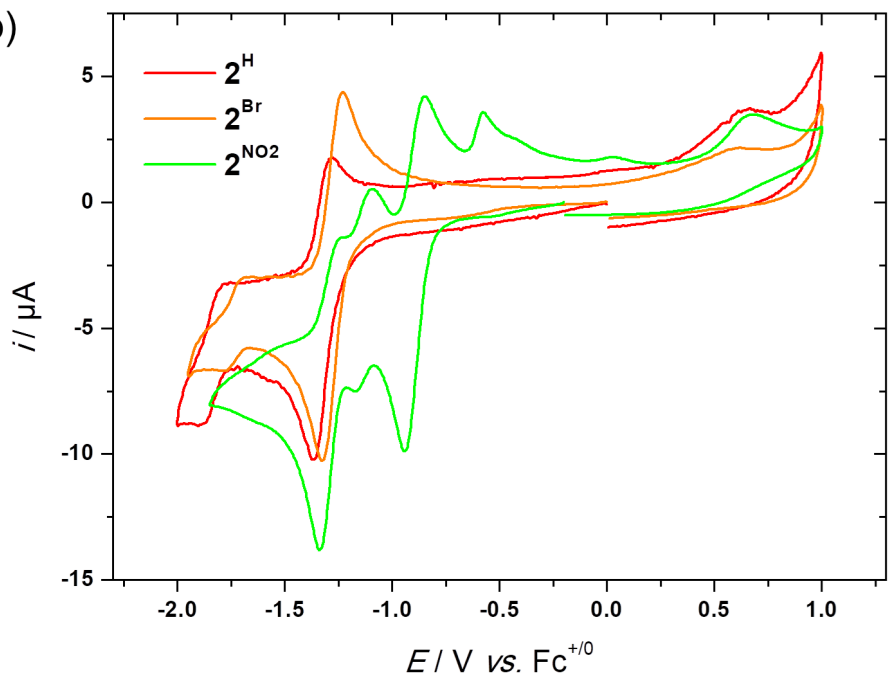

Figure S21. CVs at a glassy carbon working electrode of $2^{\mathrm{R}}(0.5 \mathrm{mM})$ in dry $\mathrm{CH}_{2} \mathrm{Cl}_{2} / \mathrm{NBu}_{4} \mathrm{OTf} 0.1 \mathrm{M}(E / \mathrm{V}$ vs. $\mathrm{Fc}^{+/ 0} ; v=0.1 \mathrm{~V} / \mathrm{s}$,). (a) $\mathrm{X}=\mathrm{H}$ (red), $\mathrm{Cl}$ (green), $\mathrm{NMe}_{2}$ (blue); (b) $\mathrm{X}=\mathrm{H}$ (red), $\mathrm{Br}$ (orange), $\mathrm{NO}_{2}$ (light green). 


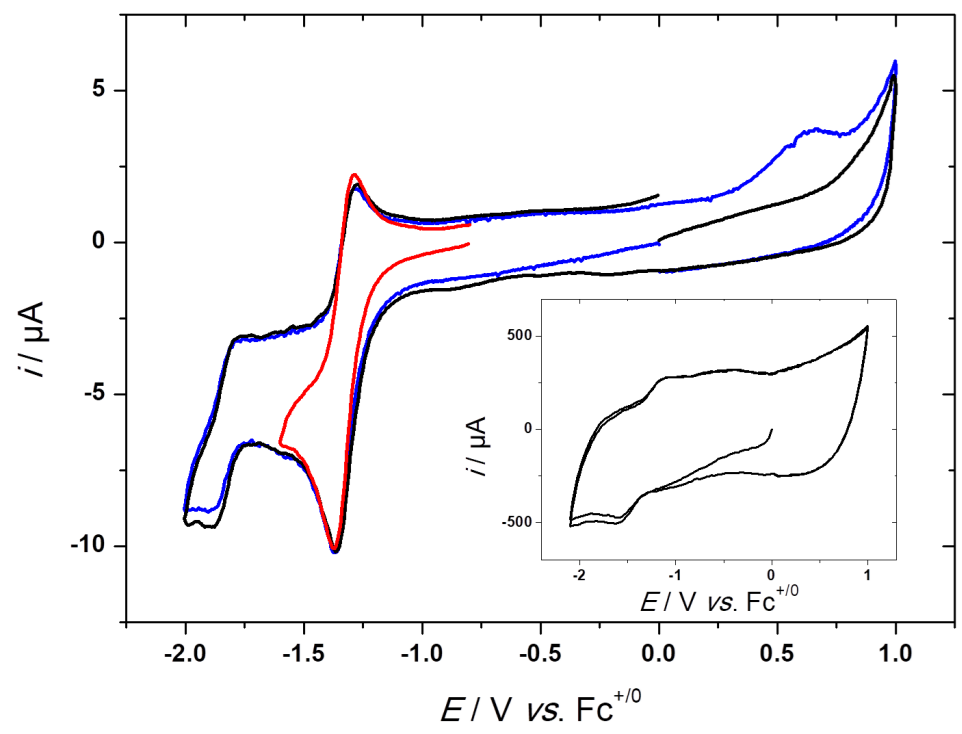

Figure S22. CVs at a glassy carbon working electrode of $2^{\mathrm{H}}(0.5 \mathrm{mM})$ in dry $\mathrm{CH}_{2} \mathrm{Cl}_{2}$ with $0.1 \mathrm{M} \mathrm{NBu}_{4} \mathrm{OTf}(E / \mathrm{V}$ $v s . \mathrm{Fc}^{+/ 0}, v=0.1 \mathrm{~V} / \mathrm{s}$ ) scanning positive (black curve) or negative (blue curve); Red curve: scan on the first reversible system in reduction. Inset: 2 cycles at $v=50 \mathrm{~V} / \mathrm{s}$. 

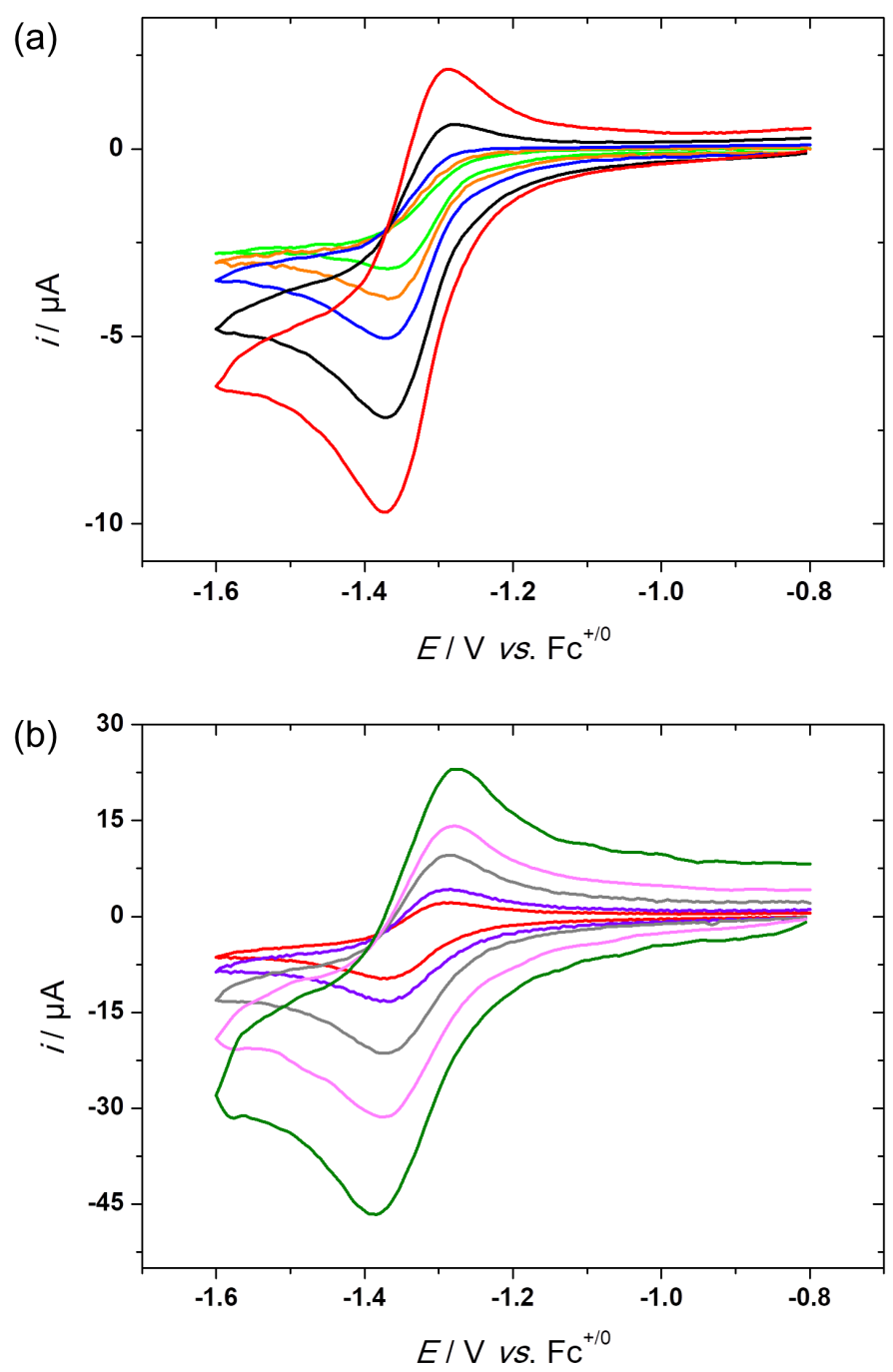

Figure S23. CVs at a glassy carbon working electrode of $2^{\mathrm{H}}(0.5 \mathrm{mM})$ in $\operatorname{dry} \mathrm{CH}_{2} \mathrm{Cl}_{2}$ with $0.1 \mathrm{M} \mathrm{NBu} \mathrm{U}_{4} \mathrm{OTf}(\mathrm{E} / \mathrm{V}$ vs. $\mathrm{Fc}^{+/ 0}, v=0.1 \mathrm{~V} / \mathrm{s}$ ) at different scan rate. (a) $v=0.01 \mathrm{~V} / \mathrm{s}$ (light green), $0.02 \mathrm{~V} / \mathrm{s}$ (orange), $0.03 \mathrm{~V} / \mathrm{s}$ (blue), $0.05 \mathrm{~V} / \mathrm{s}$ (black), $0.1 \mathrm{~V} / \mathrm{s}$ (red). (b) $v=0.1 \mathrm{~V} / \mathrm{s}$ (red), $0.2 \mathrm{~V} / \mathrm{s}$ (purple), $0.5 \mathrm{~V} / \mathrm{s}$ (grey), $1 \mathrm{~V} / \mathrm{s}$ pink), $2 \mathrm{~V} / \mathrm{s}$ (green). 


\section{b) Exhaustive electrolysis of ligand $2^{\mathrm{Cl}}$}

(a)

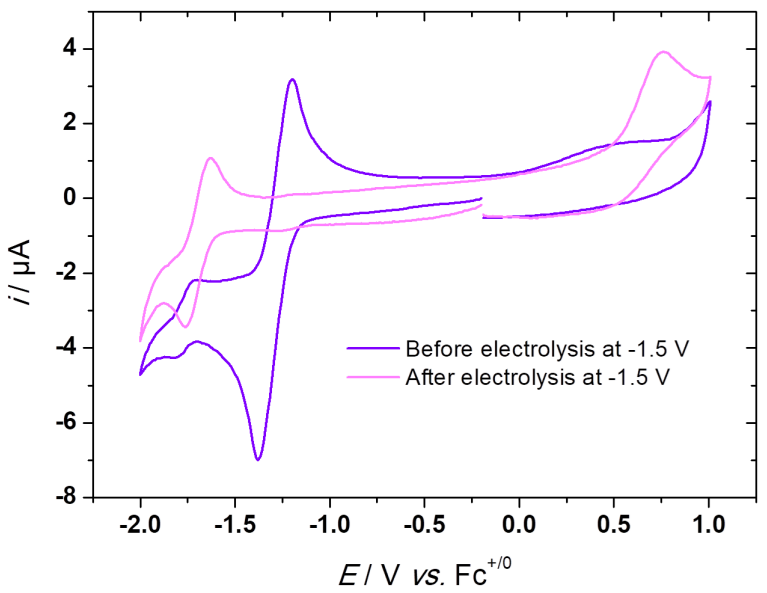

(b)

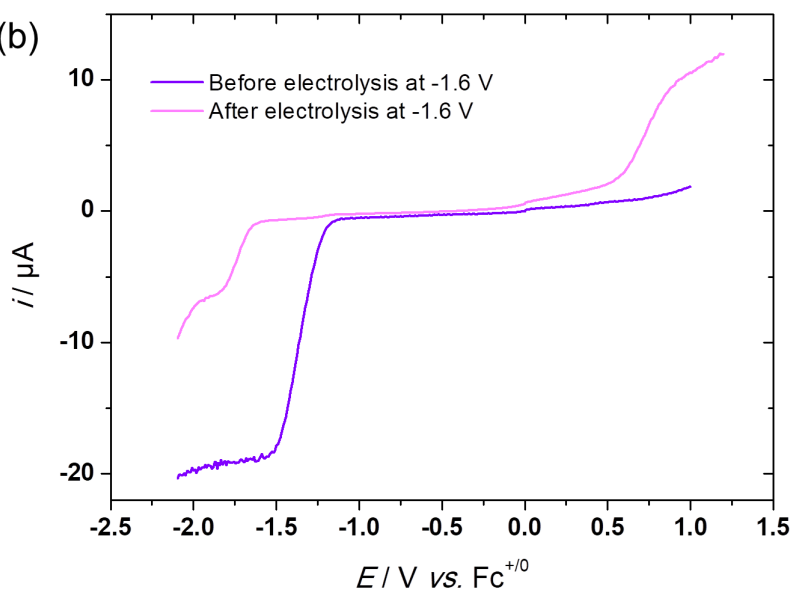

Figure S24. (a) CVs $(v=0.1 \mathrm{~V} / \mathrm{s})$ and $(\mathrm{n}) \operatorname{RDEVs}(\omega=700 \mathrm{RPM})$ at a glassy carbon working electrode $(E / \mathrm{V} v \mathrm{~s}$. $\mathrm{Fc}^{+/ 0}$ ) of $2^{\mathrm{Cl}}(0.4 \mathrm{mM})$ in dry $\mathrm{CH}_{2} \mathrm{Cl}_{2}, \mathrm{NBu}_{4} \mathrm{OTf} 0.1 \mathrm{M}$, before (purple curve) and after (pink curve) electrolysis at $-1.6 \mathrm{~V}$.

\section{c) $\mathrm{CV}$ monitoring of the addition of $2^{\mathrm{R}}$ on $\left[\mathrm{Cu}^{\prime}(\mathrm{TMPD})\right]^{+}, 1$}

Voltammetric studies of the TMPD ligand and its $\mathrm{Cu}(\mathrm{I})$ complex, 1, are displayed on Figure S25. The ligand is characterized by two well-defined irreversible oxidation peaks at $0.43 \mathrm{~V}$ and $0.64 \mathrm{~V}$ vs Fc (Figure $5 \mathrm{~A}$, red curve). It can be ascribed to the oxidation of both nitrogen atoms, leading to the formation of ammonium radicals which can dimerize or react with the solvent. Addition of 1 molar equivalent $\left[\mathrm{Cu}^{\prime}\left(\mathrm{CH}_{3} \mathrm{CN}\right)_{4}\right](\mathrm{OTf})$ induces the disappearance of both oxidation peaks and the appearance of a new irreversible oxidation peak at $E_{\mathrm{pa}}=0.07 \mathrm{~V}$ (Figure S25A, black curve). By comparison with $\left[\mathrm{Cu}^{\prime}\left(\mathrm{CH}_{3} \mathrm{CN}\right)_{4}\right]^{+}$(Figure S25A, inset), the redox behavior can be attributed to the oxidation of the $\left[\mathrm{Cu}^{\prime}(\mathrm{TMPD})\right]^{+}$complex $\mathbf{1}$ for which both $\mathrm{N}$ donors are coordinated to the metal ion. CV monitoring was also performed by inverting the addition order (TMPD on $\left.\left[\mathrm{Cu}^{\prime}\left(\mathrm{CH}_{3} \mathrm{CN}\right)_{4}\right]^{+}\right)$. As shown in Figure 5B (inset), the resulting CV is similar since an irreversible oxidation peak at $0.07 \mathrm{~V}$ is detected. Reversibility is obtained for this system by increasing the scan rate $(v>0.5 \mathrm{~V} / \mathrm{s})$.

Subsequent addition $2^{\mathrm{Br}}$ to the solution of 1 leads to the appearance of new reduction peaks at $-0.84 \mathrm{~V}$ (irreversible), $-1.30 \mathrm{~V}$ (reversible), and $-1.74 \mathrm{~V}$ vs Fc (reversible) (Figure $5 \mathrm{C}$, green curve) while the irreversible oxidation peak at $0.05 \mathrm{~V}$ remains present even when scanning positively from the open-circuit potential. Addition of a second molar equivalent of $\mathbf{2}^{\mathrm{Br}}$ increases only the peak current of the second reduction system at $-1.30 \mathrm{~V}$. This is confirmed by rotating disk electrode voltammetry (RDEV) experiments (Figure S25D). Scanning until $-1.0 \mathrm{~V}$ shows that the first reduction system remains irreversible (Figure S25D, inset). Altogether, these data indicate that stoichiometric reaction of $\mathbf{2}^{\mathrm{Br}}$ with 1 leads probably to the formation of the $\mathbf{3}^{\mathrm{Br}}$ complex which can be reduced irreversibly at $-0.84 \mathrm{~V}$. Over-stoichiometric amounts $2^{\mathrm{Br}}$ result in the $-1.30 \mathrm{~V}$ reduction wave as previously detected (see text). 
(a)

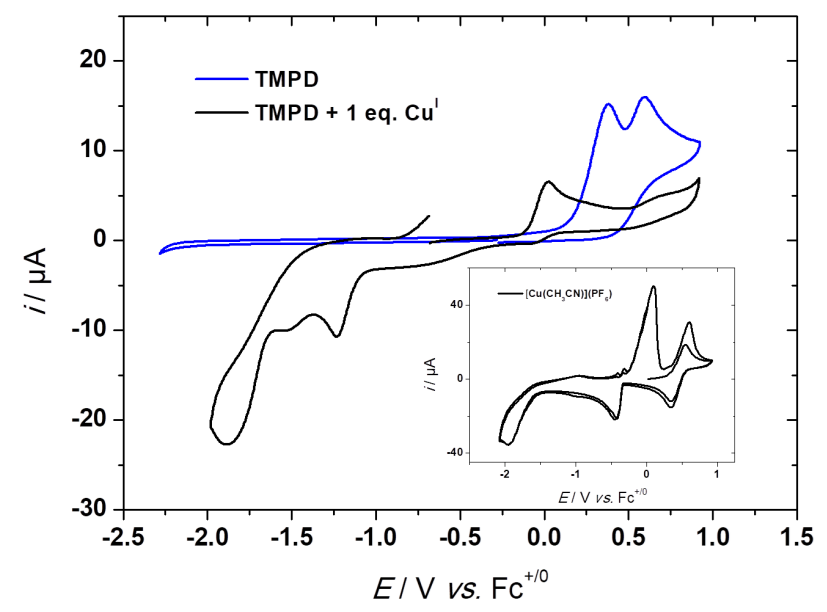

(c)

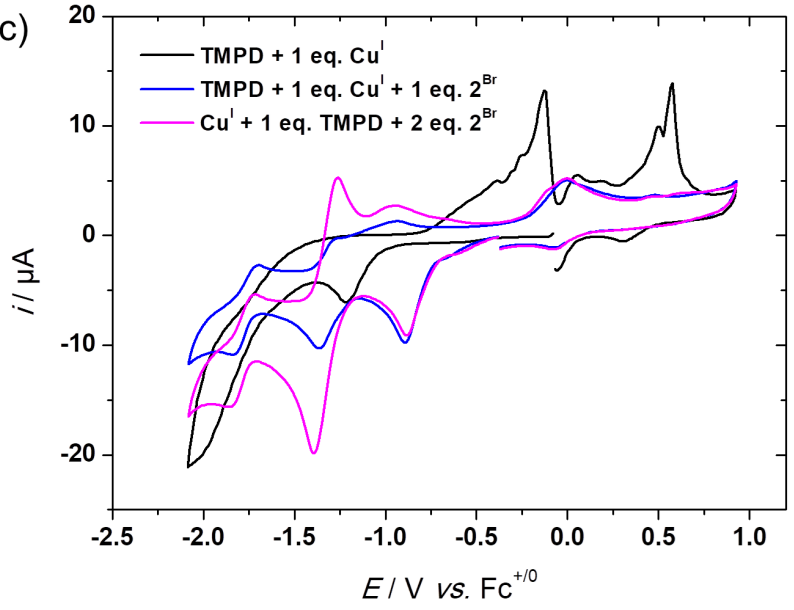

(b)
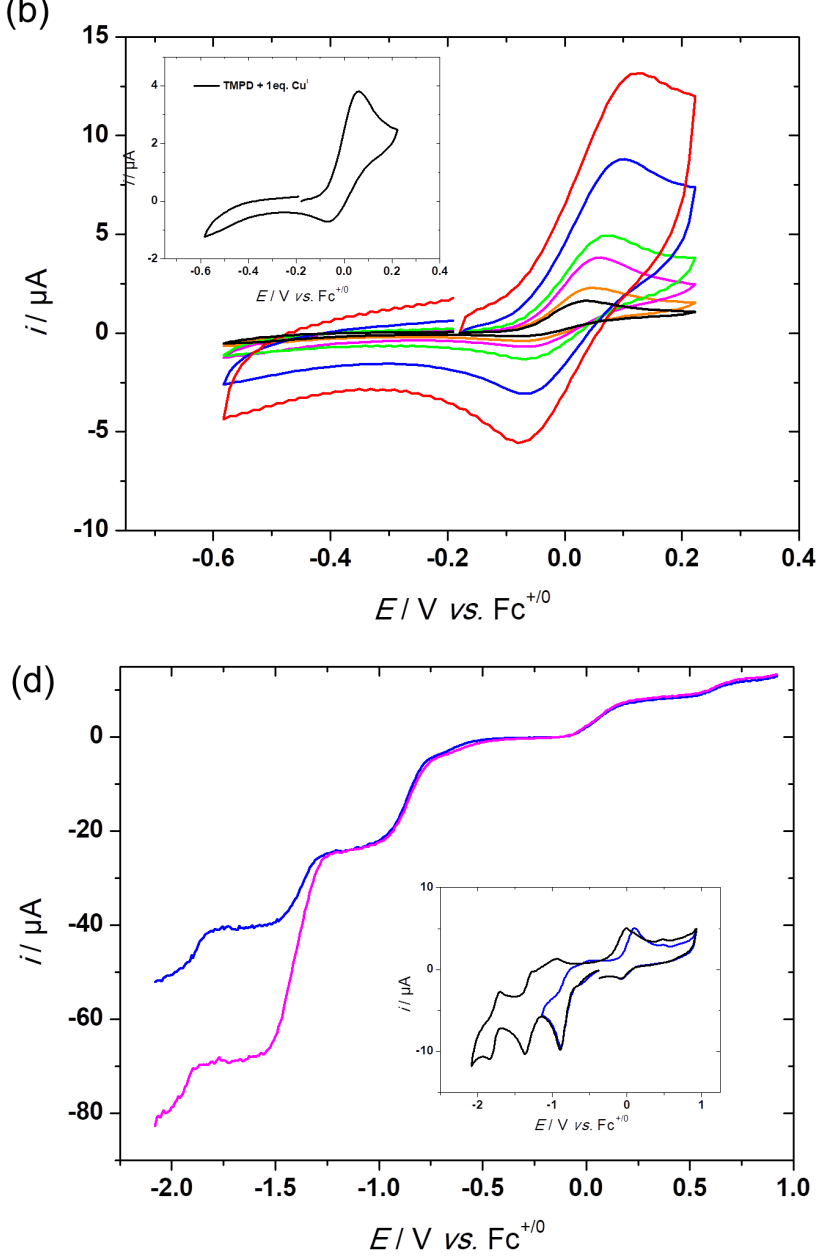

Figure S25. CVs and RDEVs at a vitreous carbon working electrode in dry $\mathrm{CH}_{2} \mathrm{Cl}_{2} / \mathrm{NBu}_{4} \mathrm{OTf} 0.1 \mathrm{M}(\mathrm{E} / \mathrm{V}$ vs. $\mathrm{Fc})$ of (A) TMPD $(0.5 \mathrm{mM})$ before (red) and after (black) addition of 1 molar equivalent of $\left[\mathrm{Cu}^{\prime}\left(\mathrm{CH}_{3} \mathrm{CN}\right)_{4}\right](\mathrm{OTf}),(v=0.1 \mathrm{~V} / \mathrm{s})$ Inset : $\left[\mathrm{Cu}^{\prime}\left(\mathrm{CH}_{3} \mathrm{CN}\right)_{4}\right](\mathrm{OTf})(0.3 \mathrm{mM}, 2 \mathrm{cycles}) ;(\mathrm{B})\left[\mathrm{Cu}^{\prime}\left(\mathrm{CH}_{3} \mathrm{CN}\right)_{4}\right](\mathrm{OTf})(0.5$ $\mathrm{mM})$ after addition of 1 molar equivalent of TMPD $(0.02 \mathrm{~V} / \mathrm{s}<v<1 \mathrm{~V} / \mathrm{s})$. Inset: $(v=0.1 \mathrm{~V} / \mathrm{s})$; (C) CVs $(v=0.1$ $\mathrm{V} / \mathrm{s}$ ) and (D) RDEVs before (black) and after addition of 1 (blue) and 2 (magenta) molar equivalents of $\mathbf{2}^{\mathrm{Br}}$ on $\left[\mathrm{Cu}^{\prime}\left(\mathrm{CH}_{3} \mathrm{CN}\right)_{4}\right](\mathrm{OTf})+$ TMPD. Inset: CVs after 1 molar equivalent of added $\mathbf{2}^{\mathrm{Br}}$. 
d) Cyclic voltammetry of $3^{\mathrm{H}}$ and $3^{\mathrm{NMe2}}$

(a)

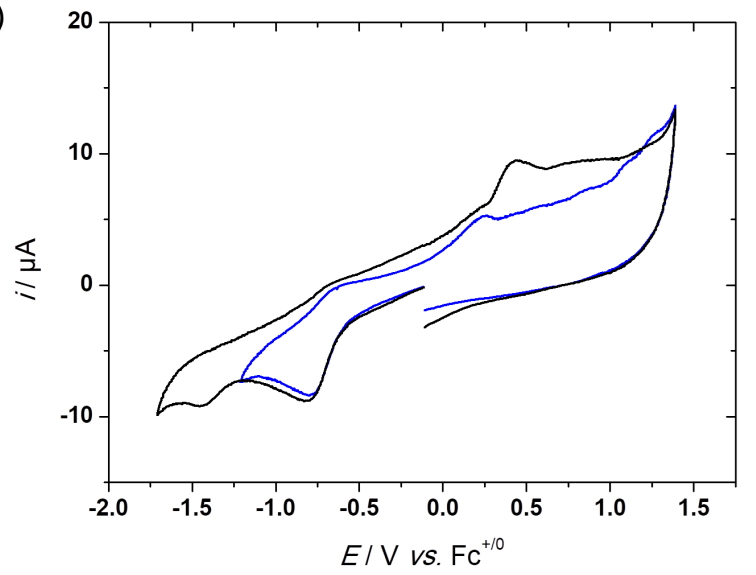

(b)

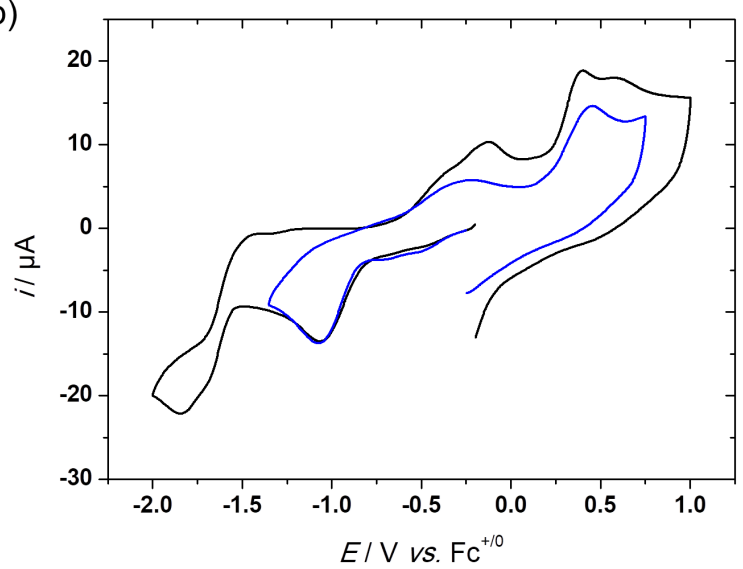

Figure S26. CVs at a vitreous carbon working electrode $\left(E / \mathrm{V} v s . \mathrm{Fc}^{+/ 0}, v=0.1 \mathrm{~V} / \mathrm{s}\right)$ of (a) $\mathbf{3}^{\mathrm{H}}$ and (b) $\mathbf{3}^{\mathrm{NMe} 2}$ in dry $\mathrm{CH}_{2} \mathrm{Cl}_{2}, \mathrm{NBu}_{4} \mathrm{OTf} 0.1 \mathrm{M}$, for different potential ranges.

\section{e) Cyclic voltammetry of $3^{\mathrm{NO2}}$}
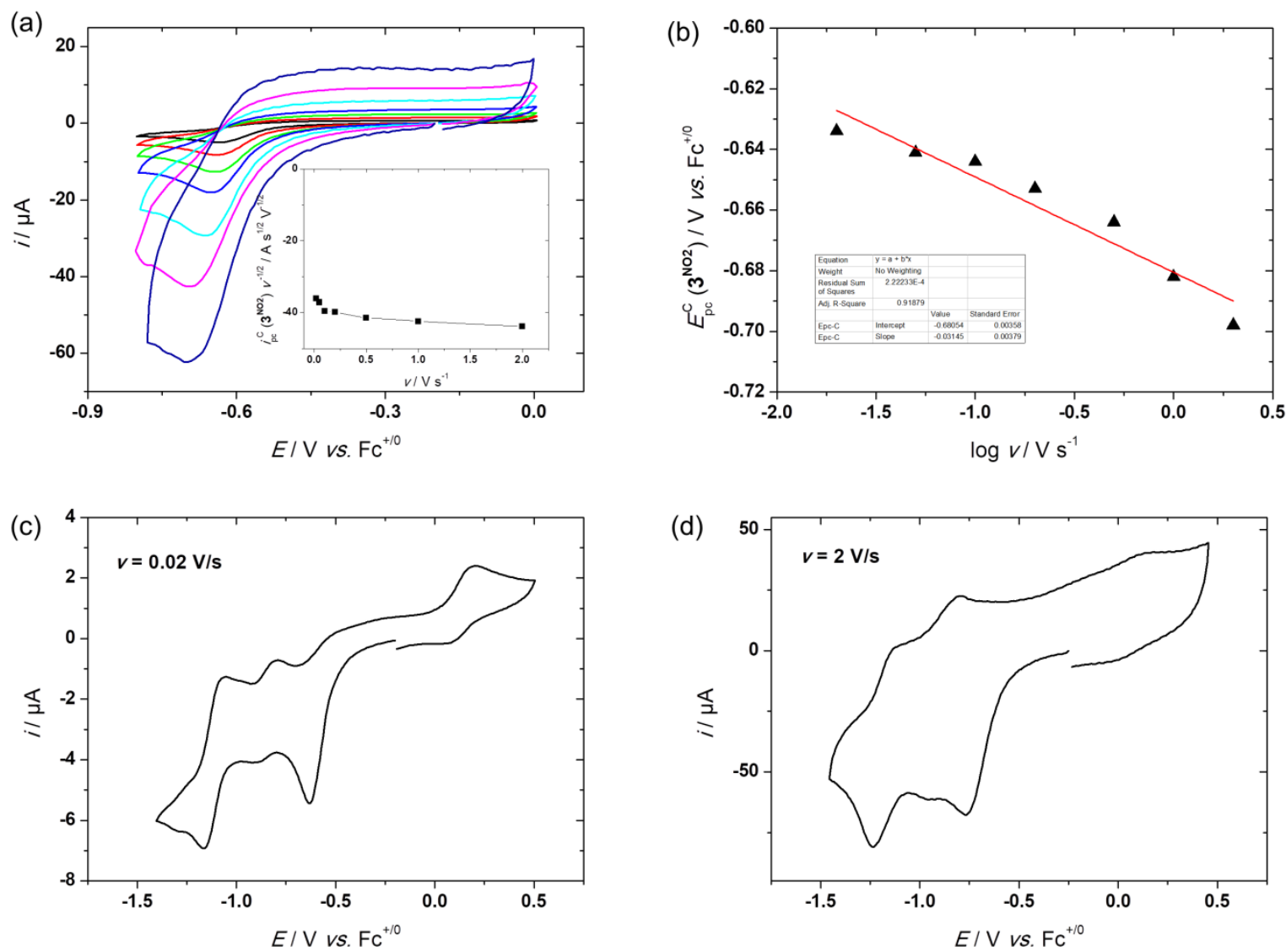

Figure S27. (a), (c) and (d) CVs at a glassy carbon working electrode $\left(E / \mathrm{V} v \mathrm{~s} . \mathrm{Fc}^{+/ 0}\right)$ of $\mathbf{3}^{\mathrm{NO2}}(0.6 \mathrm{mM})$ in dry $\mathrm{CH}_{2} \mathrm{Cl}_{2}, \mathrm{NBu}_{4} \mathrm{OTf} 0.1 \mathrm{M}$ for $0.02 \mathrm{~V} / \mathrm{s}<v<2 \mathrm{~V} / \mathrm{s}$. (b) Plots of $E_{\mathrm{pc}}^{\mathrm{C}}\left(3^{\mathrm{NO2}}\right) v s$. $\log v$. Inset (a) : Plots of $\left(i_{\mathrm{pc}}^{\mathrm{C}}\left(3^{\mathrm{NO2}}\right) v^{-}\right.$ ${ }^{1 / 2}$ ) vs. v. 


\section{f) Comparative voltammetric studies of ligands and complexes}

(a)

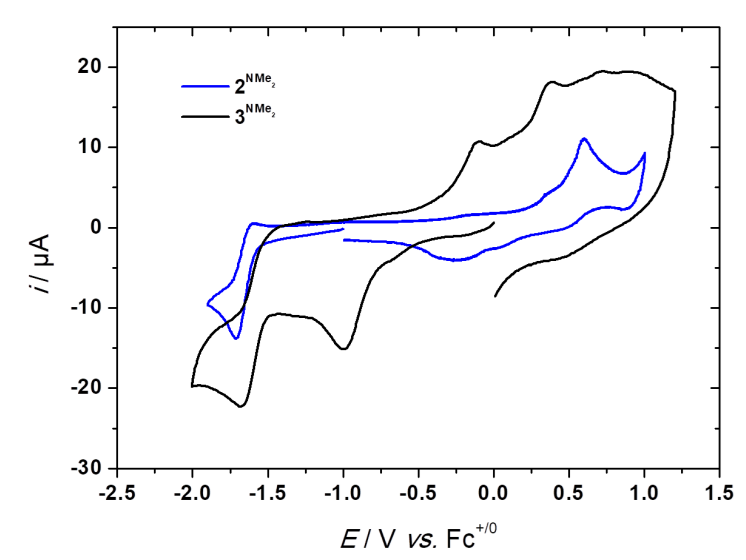

(c)

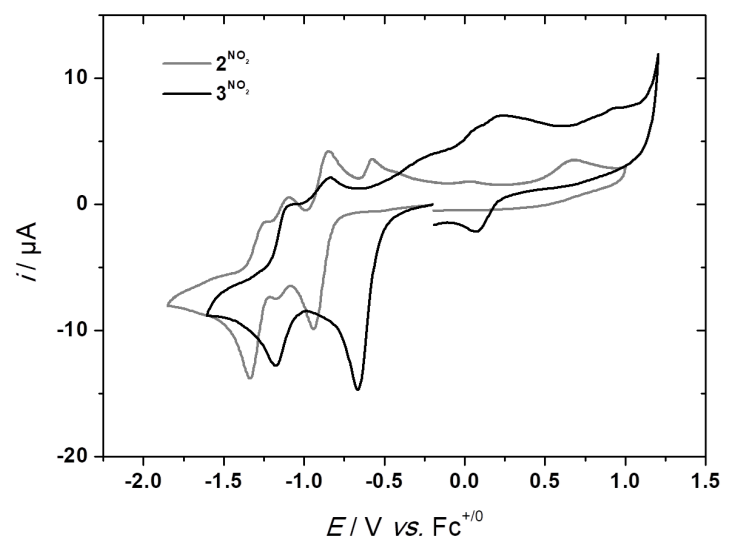

(b)

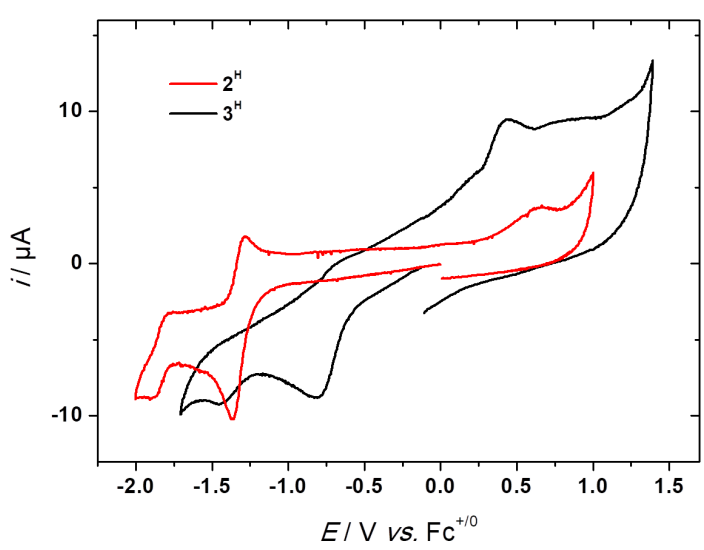

(d)

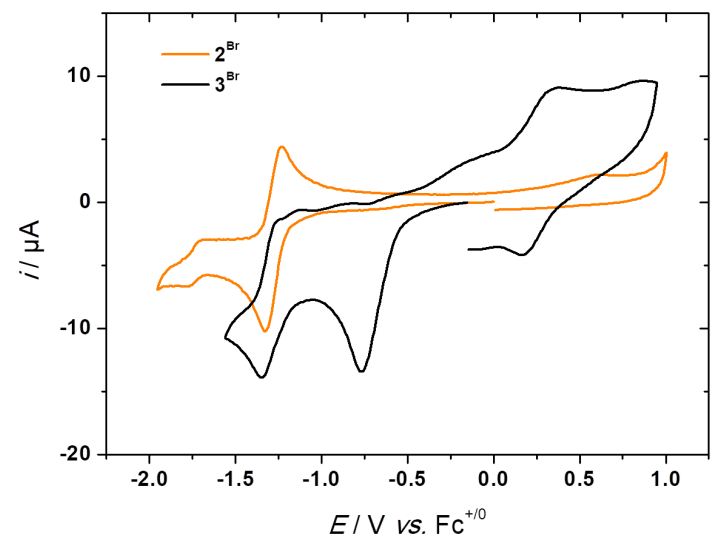

Figure S28. CVs at a glassy carbon working electrode $(E / \mathrm{V} v s$. Fc, $v=0.1 \mathrm{~V} / \mathrm{s})$ of $\mathbf{3}^{\mathrm{R}}(1.0 \mathrm{mM})$ and the associated ligand $2^{\mathrm{R}}\left(0.5 \mathrm{mM}\right.$ ) for comparison in dry $\mathrm{CH}_{2} \mathrm{Cl}_{2}, \mathrm{NBu}_{4} \mathrm{OTf} 0.1 \mathrm{M}$. (a) $\mathrm{R}=\mathrm{NMe}_{2}$; (b) $\mathrm{R}=\mathrm{H}$; (c) $\mathrm{R}=$ $\mathrm{NO}_{2} ;$ (d) $\mathrm{R}=\mathrm{Br}$. 

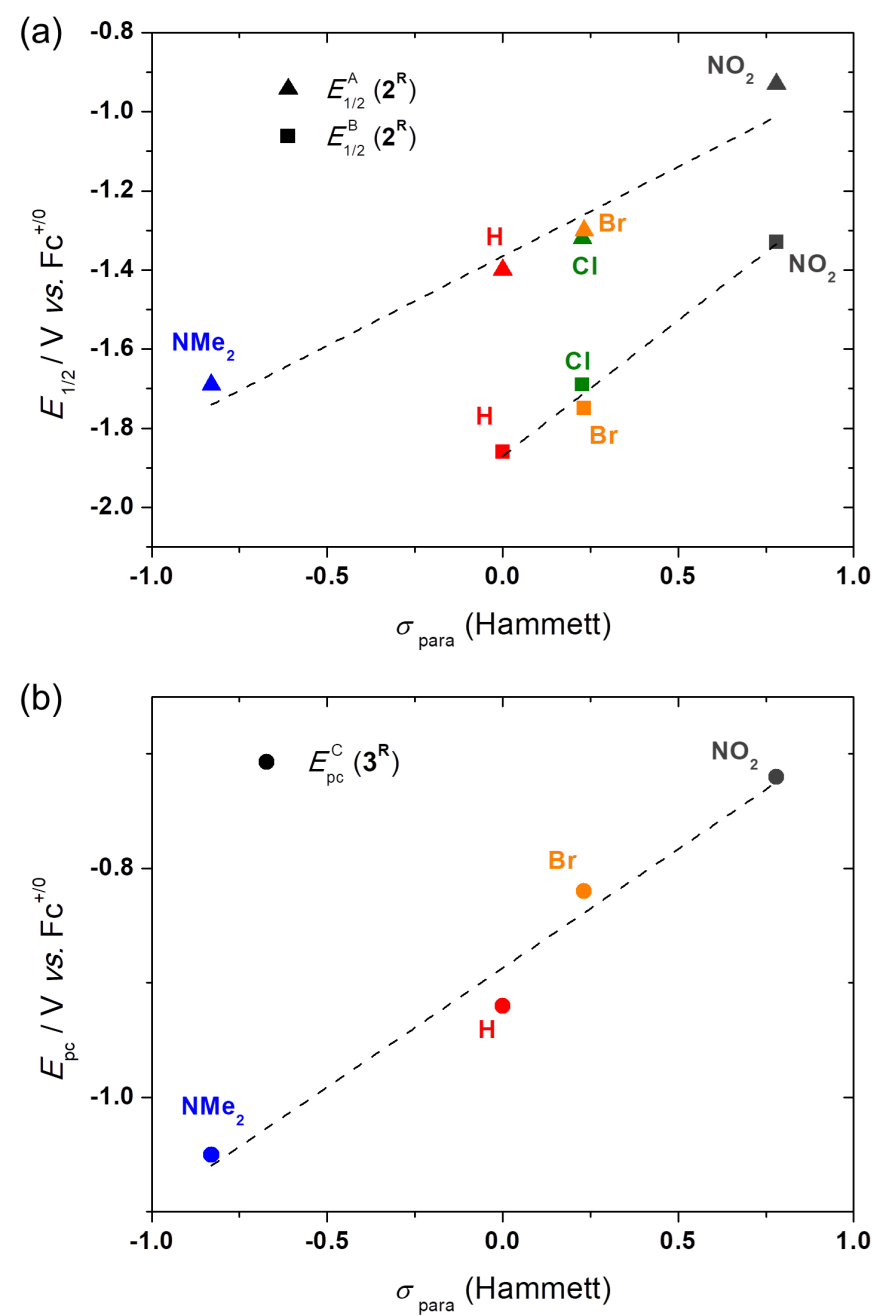

Figure S29. Plots of (a) $E_{1 / 2}^{A}\left(2^{\mathrm{R}}\right)$ and $E_{1 / 2}^{B}\left(2^{\mathrm{R}}\right)$, (b) $E_{p c}^{C}\left(3^{\mathrm{R}}\right)$ vs. $\sigma_{\text {para }}$ Hammett parameters for $\mathrm{R}$ substituents amidst $\mathrm{NMe}_{2}, \mathrm{H}, \mathrm{Br}, \mathrm{Cl}$ and $\mathrm{NO}_{2}$.

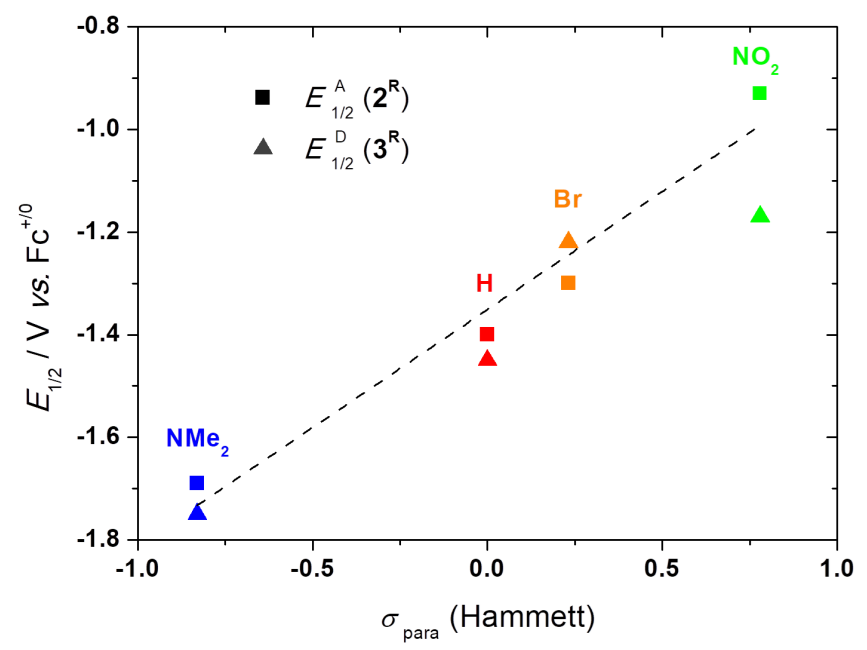

Figure S30. Plots of $E_{1 / 2}^{\mathrm{A}}\left(2^{\mathrm{R}}\right)$ and $E_{1 / 2}^{\mathrm{D}}\left(\mathbf{3}^{\mathrm{R}}\right)$ vs. $\sigma_{\text {para }}$ Hammett parameters for R substituents amidst $\mathrm{NMe}_{2}, \mathrm{H}, \mathrm{Br}$, $\mathrm{Cl}$ and $\mathrm{NO}_{2}$. 
g) Exhaustive electrolysis of complex $3^{\mathrm{NMe} 2}$

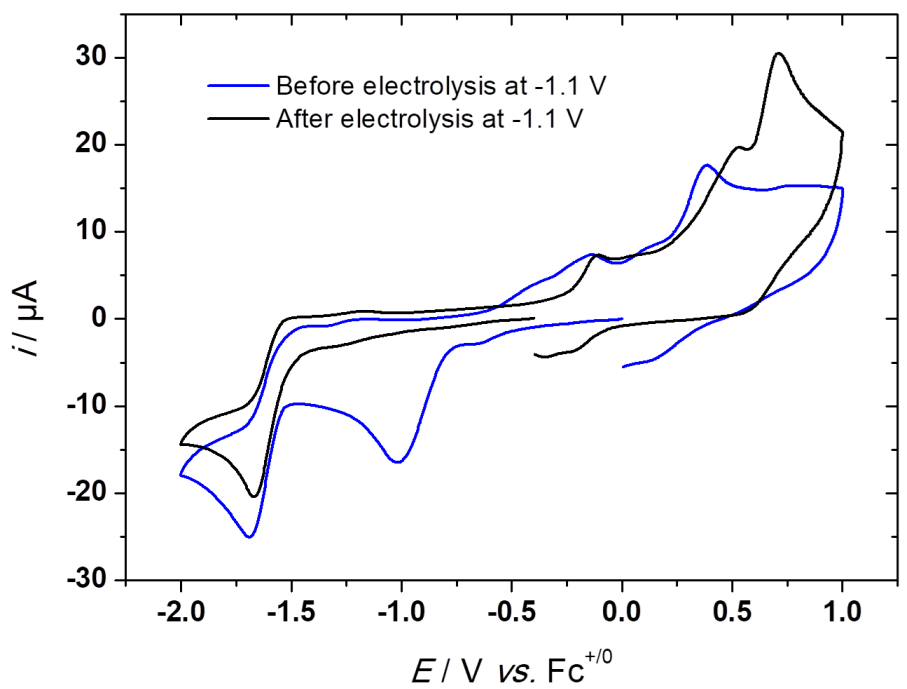

Figure S31. CVs at a glassy carbon working electrode $(E / \mathrm{V} v s$. Pc, $v=0.1 \mathrm{~V} / \mathrm{s})$ of $3^{\mathrm{NMe2}}(1.0 \mathrm{mM})$ in dry $\mathrm{CH}_{2} \mathrm{Cl}_{2}, \mathrm{NBu}_{4} \mathrm{OTf} 0.1 \mathrm{M}$. (a) before and (b) after exhaustive electrolysis at $-1.10 \mathrm{~V}$.

30 


\section{NMR data}

\section{a) ${ }^{15} \mathrm{~N}-\mathrm{NMR}$ of $2^{\mathrm{R}}$ species}

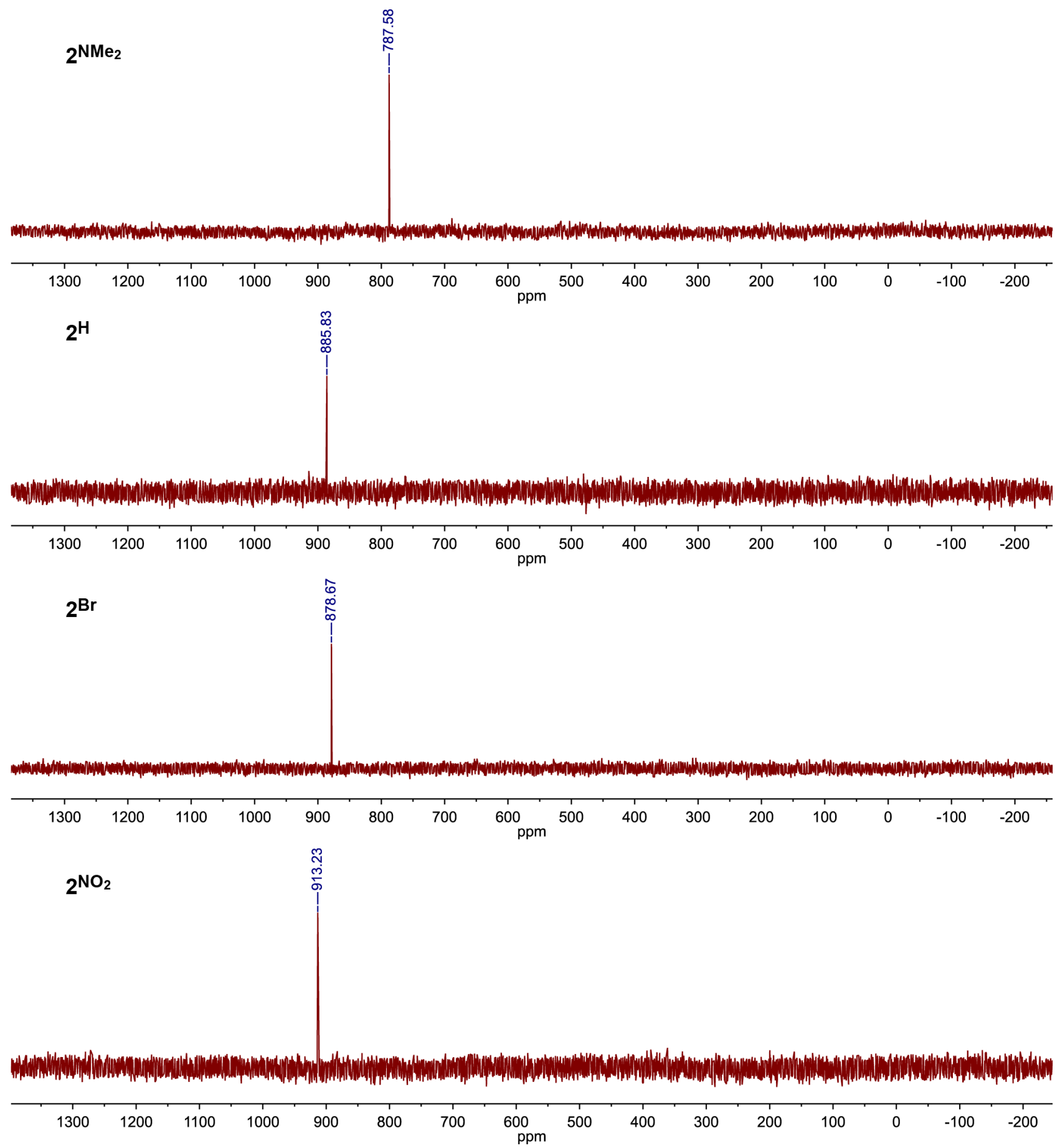

Figure $532 .{ }^{15} \mathrm{~N}-\mathrm{NMR}$ data $(50.7 \mathrm{MHz})$ of the $2^{\mathrm{R}}$ species $\left(\mathrm{R}=\mathrm{NMe}_{2}, \mathrm{H}, \mathrm{Br}, \mathrm{NO}_{2}\right)$ in $\mathrm{CDCl}_{3}$ at $25^{\circ} \mathrm{C}$. 
b) ${ }^{1} \mathrm{H}$ - and ${ }^{13} \mathrm{C}$-NMR of $3^{\mathrm{R}}$ species

1) $3^{\mathrm{NMe} 2}$

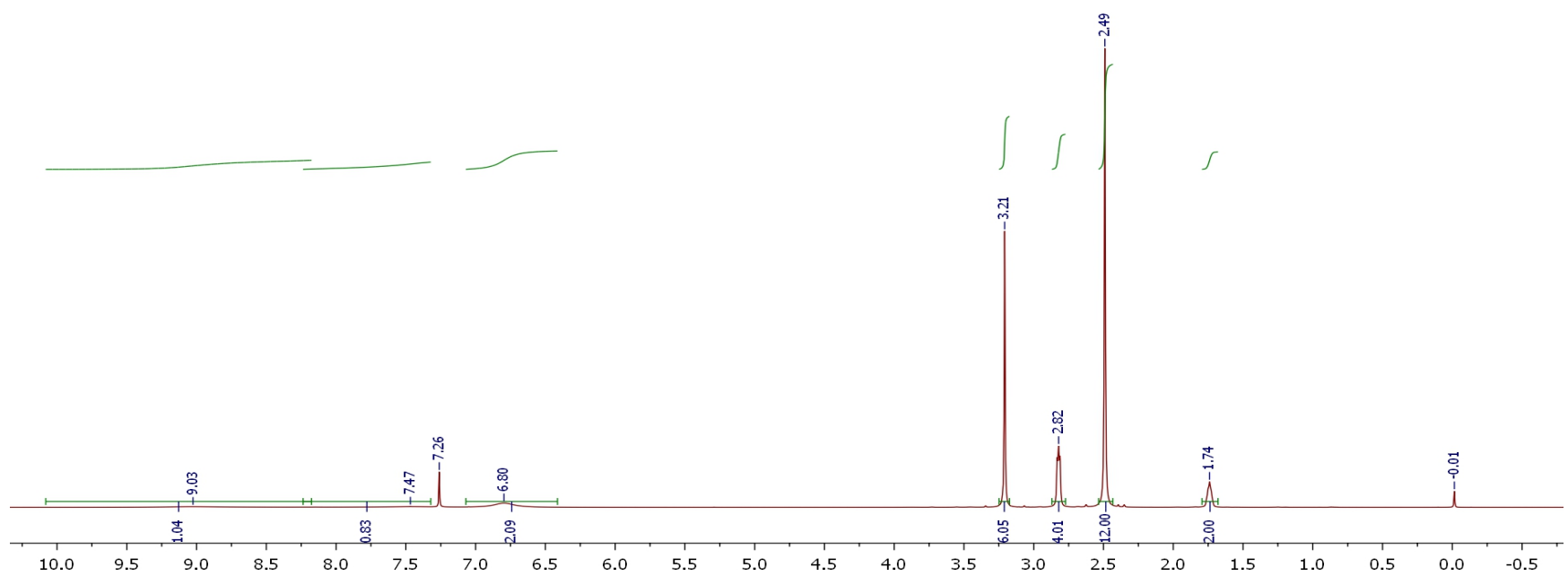

Figure S33. ${ }^{1} \mathrm{H}-\mathrm{NMR}(500 \mathrm{MHz})$ spectra of $3^{\mathrm{NMe} 2}$ in $\mathrm{CDCl}_{3}$ at $23^{\circ} \mathrm{C}$.

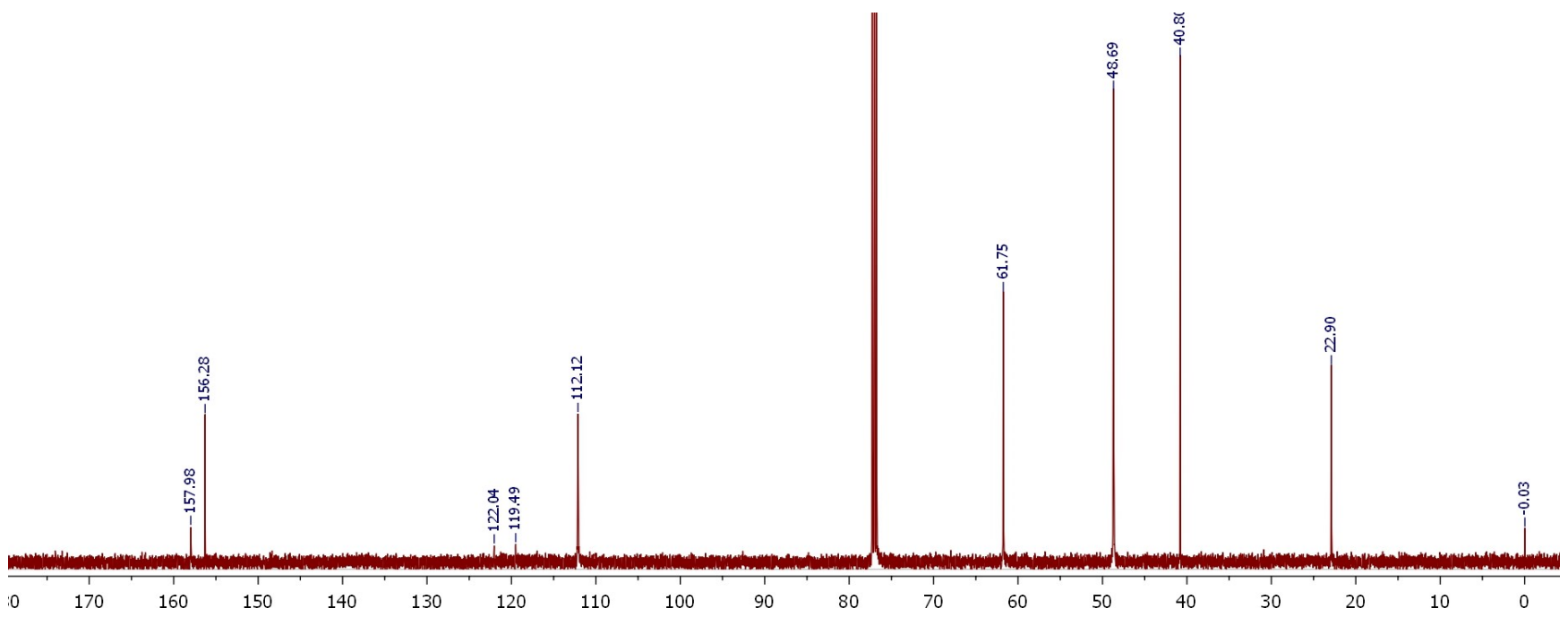

Figure S34. ${ }^{13} \mathrm{C}-\mathrm{NMR}(125 \mathrm{MHz})$ spectra of $3^{\mathrm{NMe} 2}$ in $\mathrm{CDCl}_{3}$ at $23^{\circ} \mathrm{C}$. 
2) $3^{\mathrm{H}}$

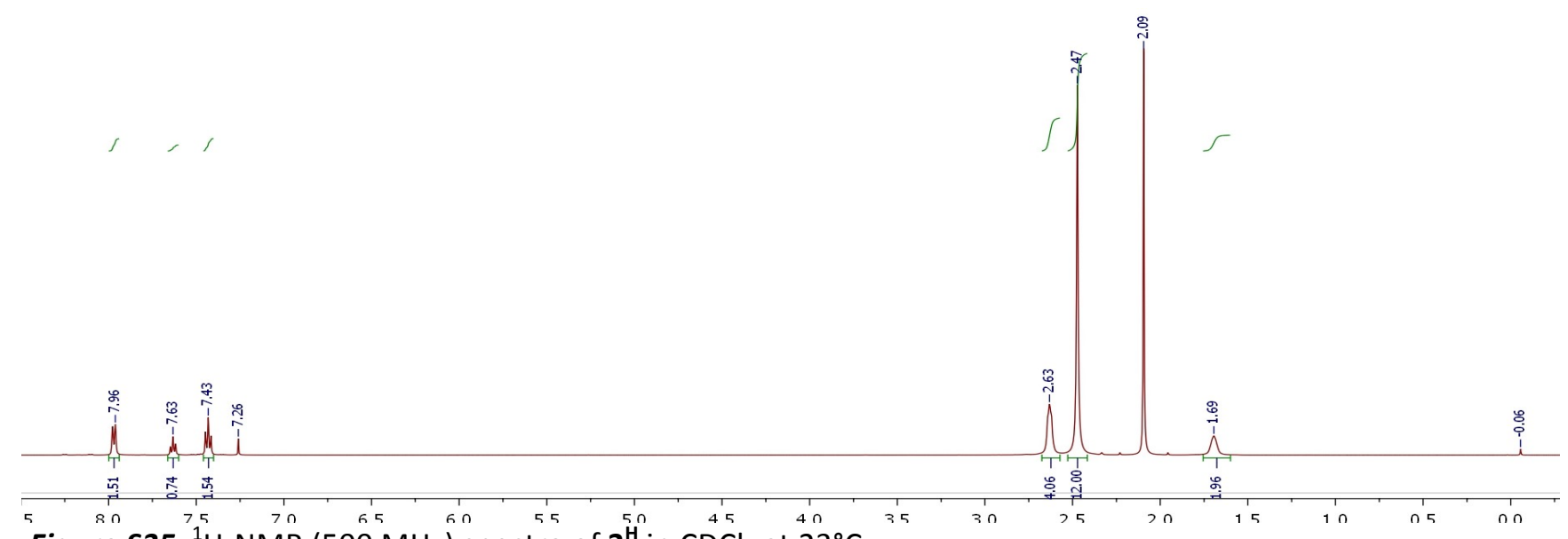

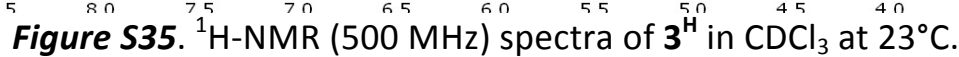

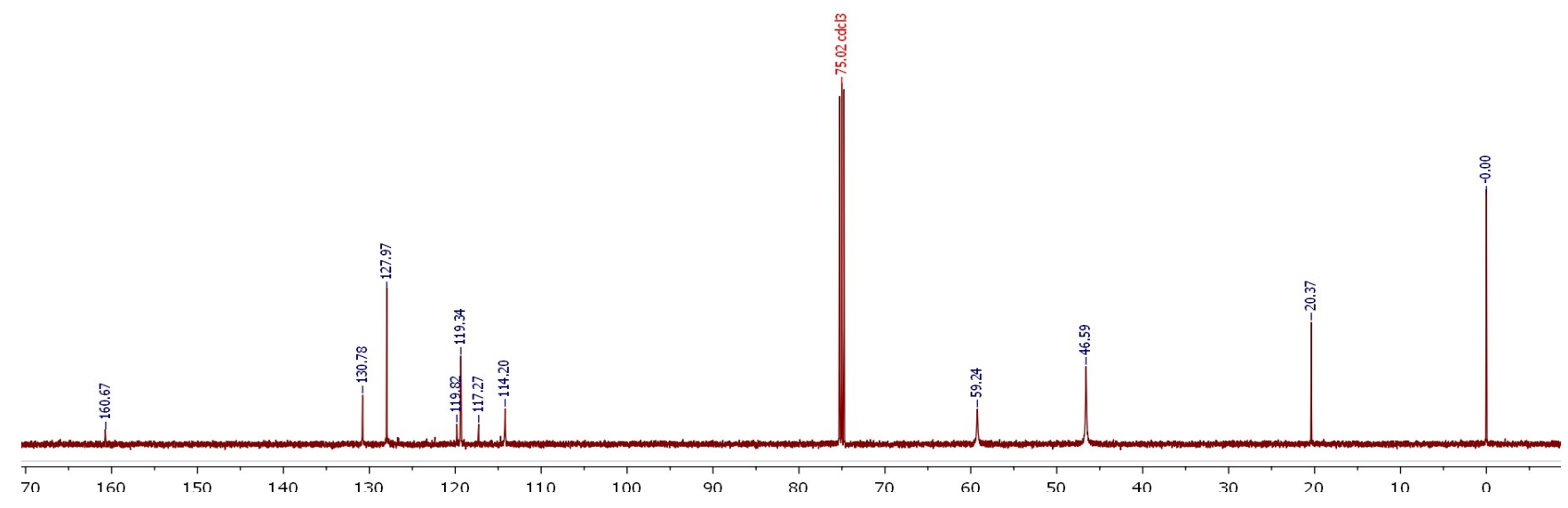

Figure S36. ${ }^{13} \mathrm{C}-\mathrm{NMR}(125 \mathrm{MHz})$ spectra of $\mathbf{3}^{\mathbf{H}}$ in $\mathrm{CDCl}_{3}$ at $23^{\circ} \mathrm{C}$. A small excess of $\mathbf{2}^{\mathrm{H}}$, visible as the small peaks in the aromatic region, was used to guarantee the 1:1 stoichiometry of the adduct.

3) $3^{\mathrm{H}^{\prime}}$

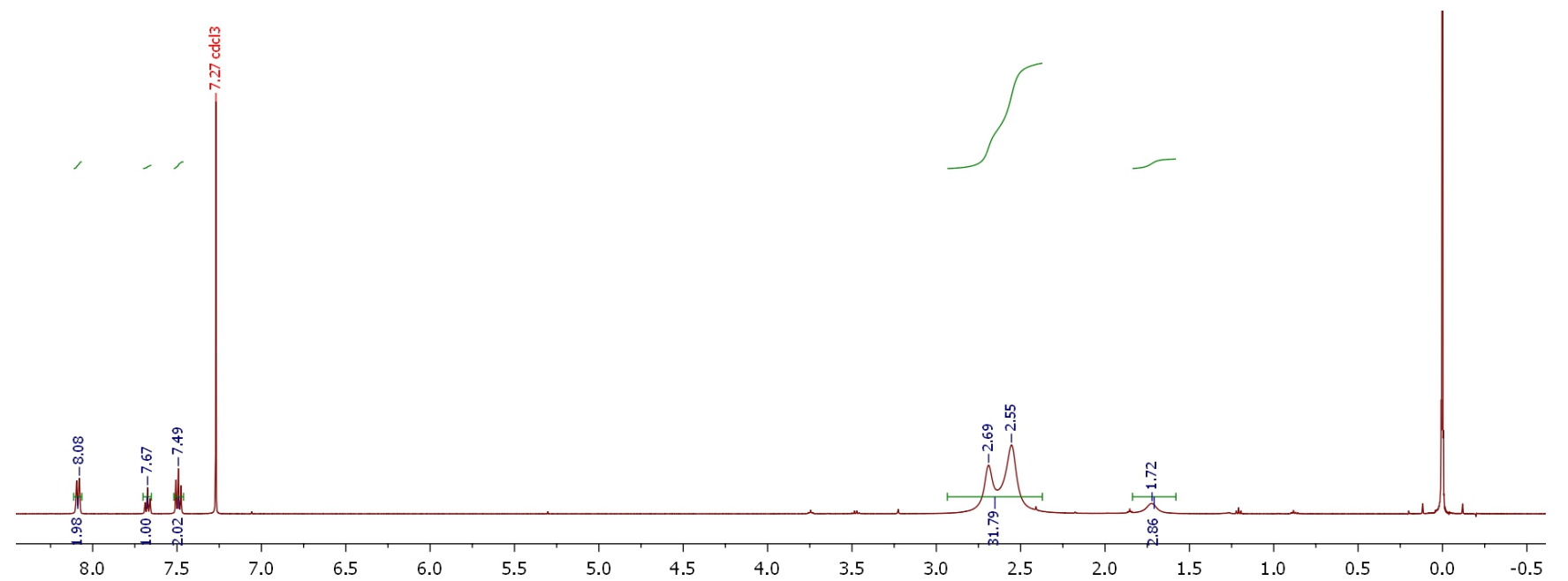

Figure S37. ${ }^{1} \mathrm{H}-\mathrm{NMR}(500 \mathrm{MHz})$ spectra of $3^{\mathrm{H}^{\prime}}$ in $\mathrm{CDCl}_{3}$ at $23^{\circ} \mathrm{C}$. 


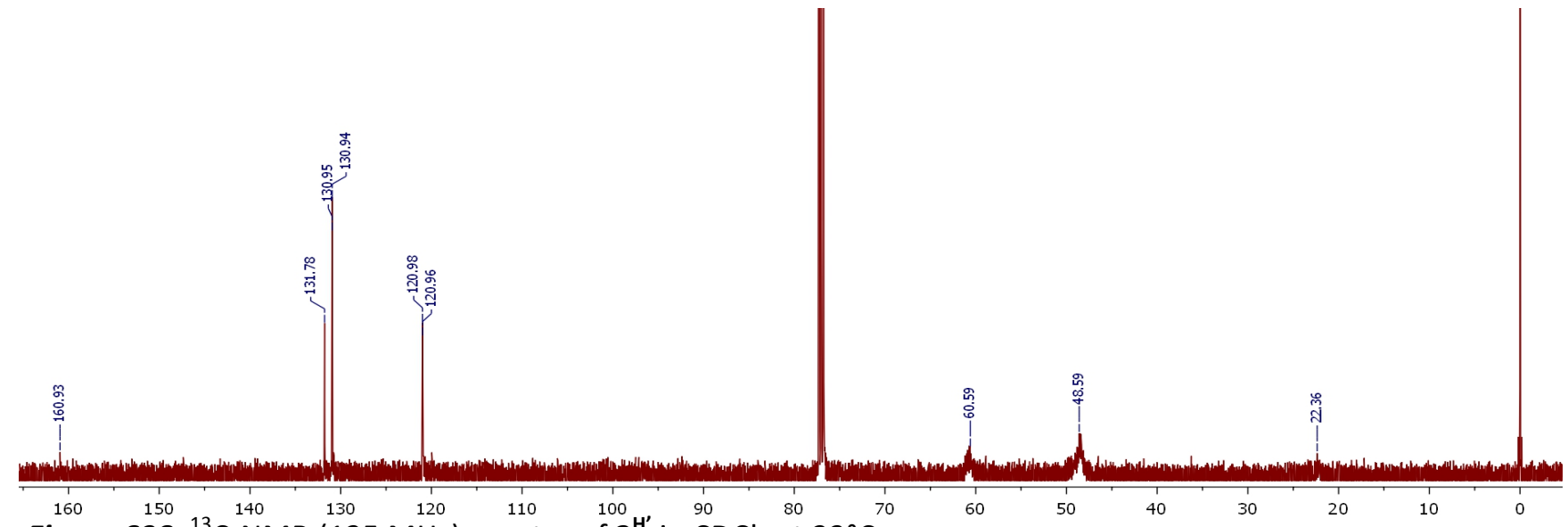

Figure S38. ${ }^{13} \mathrm{C}-\mathrm{NMR}(125 \mathrm{MHz})$ spectra of $\mathbf{3}^{\mathrm{H}^{\prime}}$ in $\mathrm{CDCl}_{3}$ at $23^{\circ} \mathrm{C}$.

4) $3^{\mathrm{Cl}}$

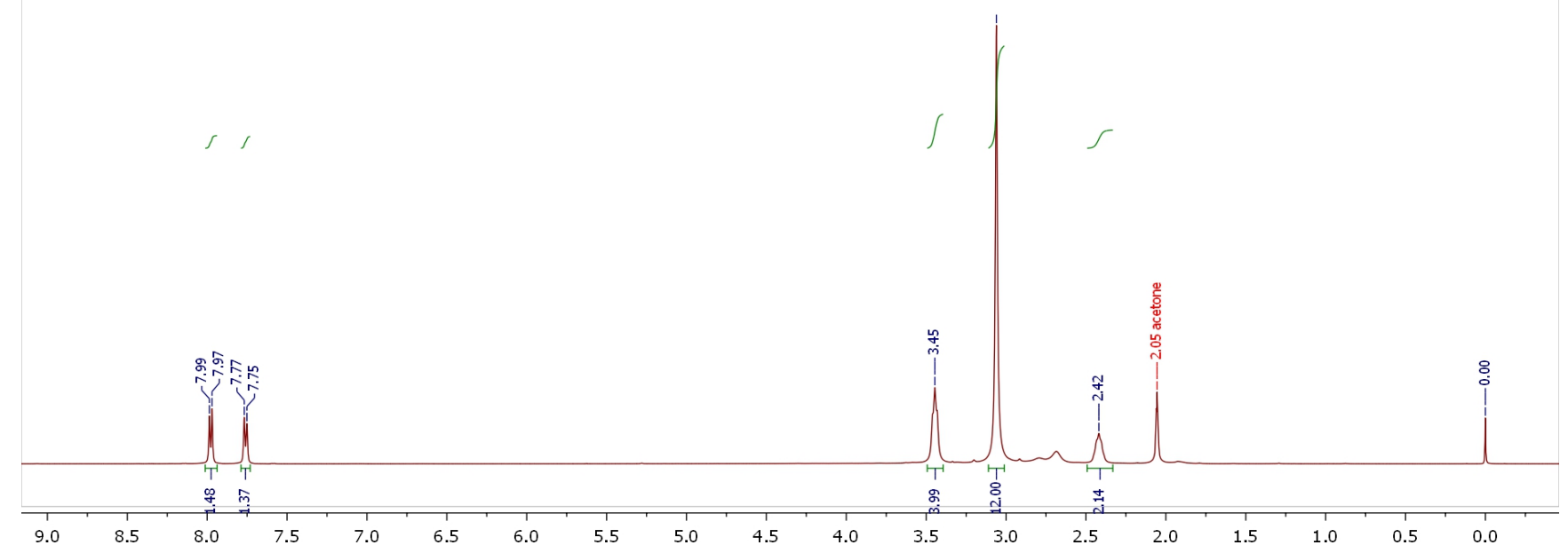

Figure S39. ${ }^{1} \mathrm{H}-\mathrm{NMR}(500 \mathrm{MHz})$ spectra of $3^{\mathrm{Cl}}$ in acetone- $d^{6}$ at $23^{\circ} \mathrm{C}$.

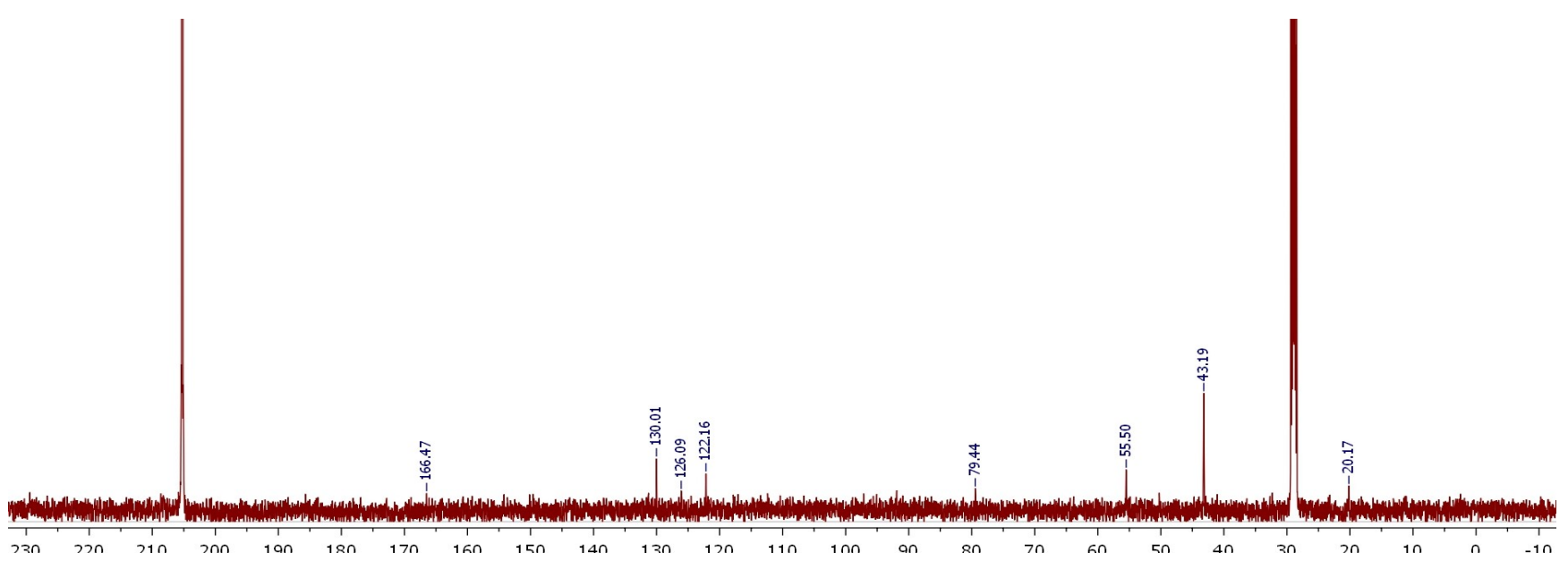

Figure S40. ${ }^{13} \mathrm{C}-\mathrm{NMR}(125 \mathrm{MHz})$ spectra of $3^{\mathrm{Cl}}$ in $\mathrm{CDCl}_{3}$ at $23^{\circ} \mathrm{C}$. 
5) $3^{\mathrm{Br}}$

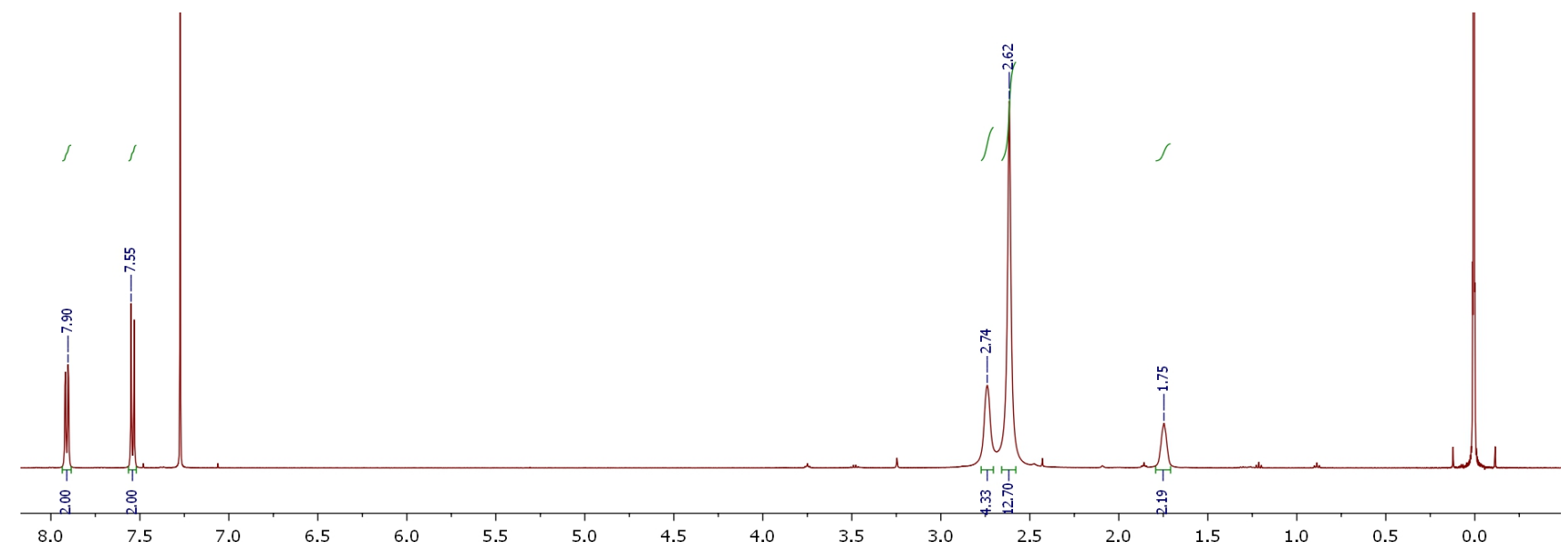

Figure S41. ${ }^{1} \mathrm{H}-\mathrm{NMR}(500 \mathrm{MHz})$ spectra of $3^{\mathrm{Br}}$ in $\mathrm{CDCl}_{3}$ at $23^{\circ} \mathrm{C}$.

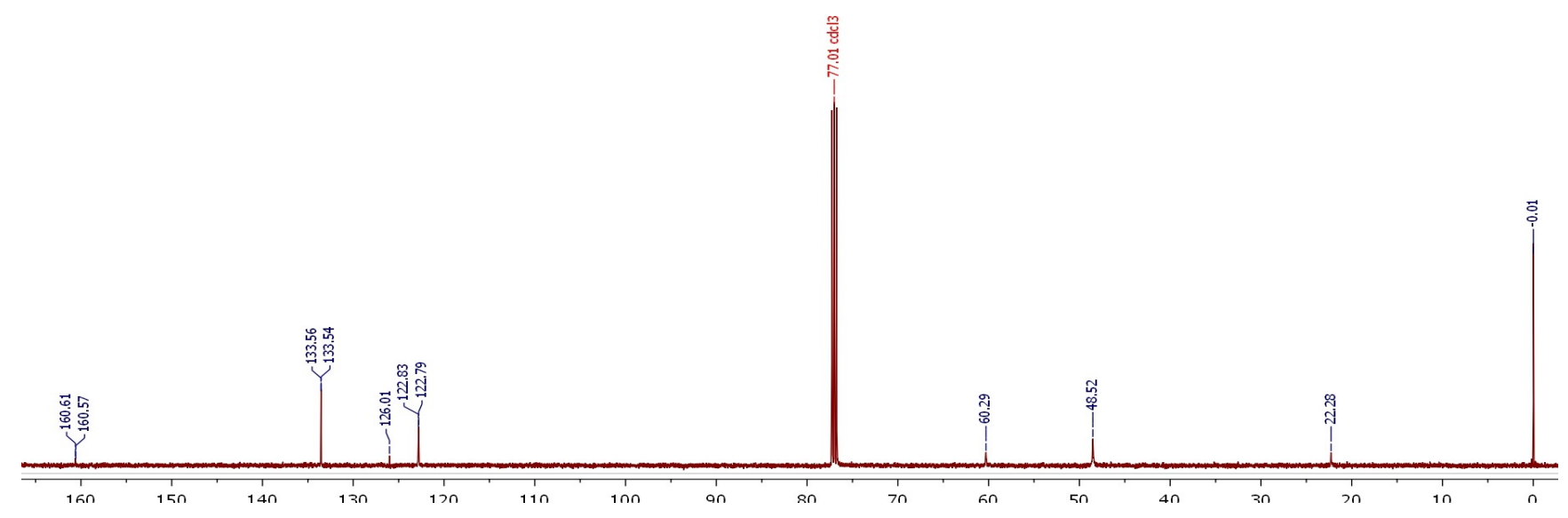

Figure S42. ${ }^{13} \mathrm{C}-\mathrm{NMR}(125 \mathrm{MHz})$ spectra of $3^{\mathrm{Br}}$ in $\mathrm{CDCl}_{3}$ at $23^{\circ} \mathrm{C}$.

6) $3^{\mathrm{NO2}}$

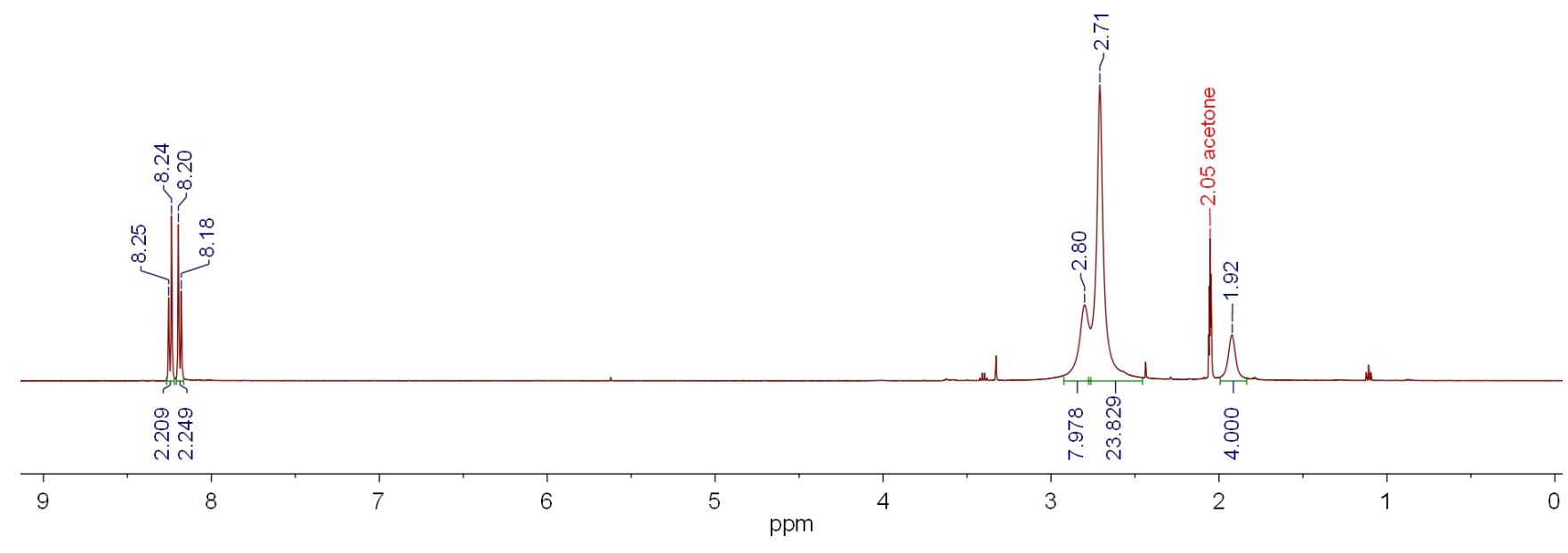

Figure S43. ${ }^{1} \mathrm{H}-\mathrm{NMR}(500 \mathrm{MHz})$ spectra of $3^{\mathrm{NO2}}$ in acetone- $d^{6}$ at $23^{\circ} \mathrm{C}$. 


\section{References}

1. Askari, M. S.; Orio, M.; Ottenwaelder, X., Controlled nitrene transfer from a tyrosinase-like arylnitrosocopper complex. Chem. Commun. 2015, 51 (56), 11206-11209.

2. Wu, G.; Zhu, J.; Mo, X.; Wang, R.; Terskikh, V., Solid-State ${ }^{17} \mathrm{O}$ NMR and Computational Studies of CNitrosoarene Compounds. J. Am. Chem. Soc. 2010, 132 (14), 5143-5155.

3. Halasz, I.; Biljan, I.; Novak, P.; Meštrović, E.; Plavec, J.; Mali, G.; Smrečki, V.; Vančik, H., Cross-dimerization of nitrosobenzenes in solution and in solid state. J. Mol. Struct. 2009, 918 (1-3), 19-25. 